Caroline Krafft ${ }^{1,}$, Ragui Assaad ${ }^{2}$ and Khandker Wahedur Rahman ${ }^{3,4}$

\title{
Introducing the Egypt Labor Market Panel Survey 2018
}

\begin{abstract}
This paper introduces the 2018 wave of the Egypt Labor Market Panel Survey (ELMPS), previously fielded in 1998, 2006, and 2012. The ELMPS has already become the primary source of data for a large number of scholarly and policy studies on the labor market and human development issues in Egypt, and this new wave will further enhance its value as a critical data public good. This longitudinal survey is nationally representative, tracking both households and individuals over two decades. In this paper, we describe the key characteristics of the 2018 wave, including sampling, fielding, and questionnaire design. Changes in the collection of retrospective data starting in 2018 are discussed, and we demonstrate that they improved the data quality. We examine the patterns of attrition and present the construction of weights designed to correct for attrition, as well as to ensure that the sample remains nationally representative. We compare the ELMPS data with other Egyptian data sources, namely, the 2017 Census and various rounds of the Labor Force Survey (LFS). The data provide important new insights into Egypt's labor market, economy, and society.
\end{abstract}

\section{Current version: Keywords:}

JEL codes: Corresponding author:
June 15, 2021

survey, panel data, public use data, sample weights, labor market,

Egypt

J00, C81, C83

Caroline Krafft

cgkrafft@stkate.edu

\footnotetext{
1 Department of Economics and Political Science, St. Catherine University, Saint Paul, MN 55105, USA

2 Humphrey School of Public Affairs, University of Minnesota, Minneapolis, MN 55455, USA

3 BRAC Institute of Governance and Development (BIGD), Brac University, Dhaka 1212, Bangladesh. The views expressed in this paper do not necessarily reflect those of BRAC University.

4 Department of Applied Economics, University of Minnesota, 1994 Ruttan Hall, St. Paul, MN 55108
}

(c) The Author(s). 2021. Open Access This article is distributed under the terms of the Creative Commons Attribution 4.0 International License (http://creativecommons.org/licenses/by/4.0/), which permits unrestricted use, distribution, and reproduction in any medium, provided you give appropriate credit to the original author(s) and the source, provide a link to the Creative Commons license, and indicate if changes were made. (e. C) Cite as: Krafft et al. IZA Journal of Development and Migration (2021) 12:12 


\section{Introduction}

The 2018 wave of the Egypt Labor Market Panel Survey (ELMPS) is the fourth wave of a longitudinal survey carried out by the Economic Research Forum (ERF) in cooperation with the Egyptian Central Agency for Public Mobilization and Statistics (CAPMAS). ${ }^{1}$ The 2018 wave follows previous waves in 1998, 2006, and 2012. The ELMPS has also served as a model for similar longitudinal surveys in Jordan (2010 and 2016) and Tunisia (2014) and an upcoming survey in Sudan (2021). ${ }^{2}$ ERF is committed to publicly available microdata as essential infrastructure for research. The ELMPS 2018 data, harmonized with previous waves of the ELMPS and the October 1988 Special Round of the Egypt Labor Force Survey (LFS), as well as the Jordan Labor Market Panel Survey (JLMPS) 2010 and 2016 and TLMPS 2014 waves, are publicly available through ERF's Open Access Microdata Initiative (OAMDI) at www.erfdataportal.com (OAMDI, 2019a, b). Data are available to researchers and for academic use.

Over its 20-year history, the ELMPS has become the mainstay of labor market and human development research in Egypt, serving as the primary data source for a large number of scholarly and policy studies both on Egypt and comparatively with other countries. Studies include three edited volumes on the Egyptian labor market (Assaad, 2002, 2009; Assaad and Krafft, 2015a), with an additional volume based on the 2018 wave forthcoming from Oxford University Press (Krafft and Assaad, 2021b). Studies using the ELMPS cover a wide variety of topics such as education and life-course transitions (Assaad et al., 2010; Assaad and Krafft, 2015b, 2021; Biltagy, 2012; Heyne and Gebel, 2016; Krafft and Assaad, 2020; Salem, 2016); inequality and inequality of opportunity (Assaad et al., 2018; Assaad and Krafft, 2016a; Belhaj Hassine, 2011; Hendy and Zaki, 2013; Said et al., 2019); migration and return migration (Bertoli and Marchetta, 2015; Binzel and Assaad, 2011; Marchetta, 2013; Wahba, 2015a); women, work, and marriage (Assaad and Arntz, 2005; Crandall et al., 2016; El-Hamidi and Said, 2014; Krafft, 2020; Miyata and Yamada, 2017; Selwaness and Krafft, 2021); work informality and job quality (Barsoum, 2015; Krafft et al., 2020; Radchenko, 2014; Selwaness and Zaki, 2017; Wahba and Assaad, 2017); and labor market dynamics (Yassin and Langot, 2018), to name only a few of the topics studied. The ELMPS has also served as the primary data source for several policy discussions and reports (Krafft and Assaad, 2015; World Bank, 2013a, b).

The panel design of the survey offers substantial advantages over pooled cross-sectional data by allowing for a more accurate assessment of change over time that controls for both observable and unobservable individual and household characteristics. It also allows for a unique perspective on life course transitions by allowing researchers to link life course outcomes like education, marriage, childbearing, migration, and employment to the individual's household characteristics during childhood and adolescence. The survey's detailed retrospective questions on education, marriage, geographic mobility, labor market histories, and fertility experience offer an additional advantage over standard LFSs that typically only include

1 ERF received generous support from several donors to undertake the 2018 wave of the ELMPS. These include the World Bank, the International Labour Organization, Agence Française de Développement, UN Women, and the Arab Fund for Economic and Social Development.

2 For additional information on the Tunisia Labor Market Panel Survey (TLMPS) 2014, see Assaad et al., (2016). For additional information on the Jordan Labor Market Panel Survey (JLMPS) 2010, see Assaad (2014). For more information on JLMPS 2016, see Krafft and Assaad (2021a). 
questions on the current status of the individual. ${ }^{3}$ Thus, the ELMPS complements the official Egyptian quarterly LFS, with a less frequent, but much richer source of longitudinal data covering a far wider variety of topics and covering them in greater depth.

As a longitudinal survey, the ELMPS attempts to track households included in the previous waves and interview all their remaining and new members. The survey also tries to locate any individuals who may have split from these households between waves, and attempts to interview them, as well as any other individuals found in the households they formed or joined. In every wave of the survey, a refresher sample of 2,000-3,000 households is added to maintain the representativeness of the overall sample and to allow for a more in-depth examination of phenomena of interest. For instance, the refresher sample of the 2012 wave of the ELMPS oversampled areas with high rates of international migration. Specifically, the 2012 wave used the 2006 Egypt Population Census estimates of migrants abroad relative to the adult population at the neighborhood/village level to identify high-migration areas (Assaad and Krafft, 2013). In rural areas, these were areas with $4 \%$ or more of adults abroad, and in urban areas, these were areas with $1 \%$ or more of adults abroad. The results from the 2012 wave (with weights that accounted for the oversampling) revealed that $7 \%$ of households had a current migrant abroad and 5\% of adults were returned migrants (Wahba, 2015b). The oversampling in the 2012 wave allowed for a more detailed examination of the patterns and effects of international migration from Egypt (Assaad and Krafft, 2013; Binzel and Assaad, 2011; El-Mallakh and Wahba, 2017; Wahba, 2015b). Similarly, the 2016 wave of the JLMPS added a 3,000-household refresher sample that oversampled neighborhoods with a high proportion of non-Jordanian households to allow for in-depth examinations of the effects of the Syrian refugee influx on Jordanian society and the situation of migrants and refugees in Jordan (Al-Hawarin et al., 2021; Assaad et al., 2018; El-Mallakh and Wahba, 2018; Fallah et al., 2019; Krafft and Assaad, 2021a; Malaeb and Wahba, 2018).

The focus we selected for the 2018 wave of the ELMPS was economic vulnerability among Egypt's poorest communities. Accordingly, we added a refresher sample of 2,000 households that oversampled rural communities that were among the "1,000 poorest villages" of Egypt, as ascertained by the most recent national poverty map available to us. ${ }^{4}$ The focus on economic vulnerability was prescient, since, although the data predate the COVID-19 pandemic, a deeper understanding of economic vulnerability pre-crisis is critically important for understanding who is vulnerable to the crisis.

The final sample included 15,746 households and 61,231 individuals. Of these households, 13,793 households included members from 2012 (10,042 panel and 3,751 split households) and 1,953 were refresher households. Among individuals, 53,040 were from households that included at least one individual interviewed in 2012 (i.e., either panel or split households), while 8,191 were in refresher households. Of the 49,186 individuals included in the 2012 sample, 39,153 (79.6\%) were successfully re-interviewed in 2018. Of the 37,140 individuals in the 2006 sample, 22,901 (61.7\%) were successfully tracked over three waves. Finally, of the 23,997 individuals included in the 1998 wave, 10,145 (42.3\%) were successfully tracked over four waves.

3 See Pastore et al., (2021) who use similar retrospective questions in the European SILC survey to study the school-to-work transition of youth in Italy, which allows for analysis not possible using standard labor force surveys. Also see Assaad et al., (2018b) for a comparison of panel and retrospective data in the labor market panel surveys and the lessons drawn from these comparisons that informed the re-design of the labor market history modules in JLMPS 2016 and ELMPS 2018.

4 We identified the "1000 poorest villages" using the 2013 poverty map, based on the 2012/2013 Household Income, Expenditure and Consumption Survey (HIECS) and the 2006 Population Census (with projected population numbers) prepared by CAPMAS in cooperation with the World Bank and UNDP. 
We present a detailed discussion of sample attrition patterns in Section 2 and the creation of weights to address such attrition in Section 3. We also discuss the design of the refresher sample and the calculation of its weights. In Section 4, we detail modifications in the design of the survey's labor market history module and demonstrate how they improved the quality of the retrospective data. In the subsequent section, we compare the (weighted) results of the ELMPS on key demographic and labor market indicators with those of other data sources, namely, Egypt's 2017 Census and various rounds of the LFS. First, however, we discuss the design of the questionnaires, sample, and fielding practices.

\section{Data Collection and Sample Attrition}

\subsection{Questionnaires}

Each wave of the survey attempts to maintain consistency for the indicators measured in previous waves while adding additional modules and questions to examine new issues or to allow more in-depth examination of existing issues. Accordingly, the 2018 wave devoted more attention to the measurement of the instability of employment, focusing in particular on job turnover among casual workers. It also provided more detailed information on health, gender role attitudes, food security, hazardous work, community infrastructure, and the cost of housing. It incorporated specific questions on vulnerability, coping strategies, and access to social safety net programs.

The 2018 wave had two primary questionnaires: a household questionnaire and an individual questionnaire. The modules in these two questionnaires are listed in Table 1. Most of the parts in the modules are the same as those in the previous waves of the survey with a few exceptions. The "tracking splits" module in the household questionnaire allows interviewers to ascertain whether the composition of the household has changed since the 2012 wave and inquire about new members present in the household as well as those who may have split to form new households. The "shocks and coping module" is also new in the 2018 wave and enquires about both idiosyncratic and community-level shocks that the household may have been exposed to, household food security, and coping mechanisms that the household may have used to respond to shocks. The main changes in the individual questionnaire relative to the 2012 wave were a substantial expansion of the health module, a reconfiguration of the labor market history module to better capture past periods of non-employment, ${ }^{5}$ and the addition of a module on attitudes. The rich variety of data allow for linking important aspects of Egyptians' lives and the labor market, both contemporaneously and through longitudinal analysis. As well as the panel data facilitating longitudinal analysis, the residential mobility history, educational history, labor market history, marital history, and fertility history allow important analyses of inter-linked life course events, ranging from the relationship between employment opportunities and fertility (Krafft, 2020), to education and internal migration (Krafft et al., 2019).

\subsection{Data collection}

The collection of data was tablet-based. The ODK-X (previously named ODK2) tools were used, given their ability to easily handle hierarchical data structures, such as multiple births

5 See Assaad et al., (2018) for a discussion of ways to improve the collection of retrospective labor market data. See Section 4 for an examination of these improvements. 
Table 1 Questionnaire modules

\begin{tabular}{ll}
\hline Household & Individual \\
\hline - Statistical identification & - Statistical identification \\
- Tracking splits & - Residential mobility \\
- Individual roster & - Father's characteristics \\
- Housing information & - Mother's characteristics \\
- Current migrants & - Siblings \\
- Transfers from individuals & - Health \\
- Other sources of income & - Education \\
- Shocks and coping & - Past 7 days subsistence and domestic work \\
- Household non-farm activities & - Employment in the past 7 days \\
- Agricultural assets: lands & - Unemployment \\
- Agricultural assets: livestock/poultry & - Employment in the past 3 months \\
- Agricultural assets: equipment & - Characteristics of the main job \\
- Agriculture: crops & - Secondary job \\
& - Labor market history \\
& - Earriage
\end{tabular}

Source: Authors' construction based on ELMPS 2018 questionnaire.

ELMPS, Egypt Labor Market Panel Survey.

to individuals within households, and validate across these different structures (Brunette et al., 2017). Training of the trainers was held at CAPMAS in January 2018. Enumerators were trained in April 2018, and data collection began in end-April. The bulk of data collection was completed by July 2018, but some teams continued to collect data until November 2018, to complete the sample. For fieldwork, teams were governorate-based and composed of a supervisor and from three to five enumerators (numbers vary depending on the sample size in the governorate). All the enumerators were women.

Based on experience from past surveys, we eschewed a distinct enumeration round (a phase of locating and listing individuals interviewed in the previous wave before fielding). From our experience in the 2012 wave, we found that the data from the enumeration phase could not simply be used directly in fielding, as individuals may have split between enumeration and fielding, and locating households twice added to the cost, time, and attrition. In fielding the ELMPS 2012, 1,680 individuals who were enumerated in 2011 were simply not found in the main fieldwork phase in 2012, and we lacked information on whether they split together, died, moved abroad, or otherwise (Assaad and Krafft, 2013). A similar problem arose in Jordan in 2016, where, although we designed the questionnaire to track splits at fielding as well as enumeration, many such splits 
were not actually fielded, leading to the loss of 616 split households and 647 individuals from the sample (Krafft and Assaad, 2021a). ${ }^{6}$ Instead of implementing a separate enumeration phase, data on the status of all 2012 members were collected as part of the main fieldwork in 2018. We processed the data regularly (multiple times per week) throughout fielding to extract split households that needed to be tracked and added them to the server database for fielding. This dynamic process also allowed us to track repeat splits, i.e., cases where individuals split together, but once located, were found to have further subdivided into additional new households.

During fieldwork, field quality control took place. We undertook an innovative quality control process where, rather than asking the quality control teams to entirely redo certain questionnaires, we randomly deleted a certain number of modules from a sample of completed questionnaires and asked the quality control teams to repeat the data collection for those modules. More critical modules had a higher probability of being selected for deletion. For example, we took a 5\% deletion rate in Section 4.0, which covers assets and housing characteristics, as these questions primarily have yes/no answers and presented fewer data quality challenges. More central modules, such as unemployment detection, were assigned a higher probability of deletion. Because certain variables such as economic activities and occupations were entered in text form and post-coded at the office, this provided a further opportunity for quality control by checking for inconsistencies and possible data entry errors.

\subsection{The 2012 sample: Attrition from 2012 to 2018}

A key goal of the ELMPS 2018 was to track ELMPS 2012 households and all their members, to be able to generate a panel of households and individuals (a panel that now spans 1998, 2006, 2012, and 2018). To maintain a representative sample (Beegle et al., 2011; Himelein, 2014; Vaillant, 2013), households and individuals were tracked, even if they migrated (so long as they remained within Egypt). Two types of attrition could occur during this process. First, entire households that were included in 2012 might be lost in 2018 . We refer to the inability to locate entire households from the 2012 wave when fielding in 2018 as Type I attrition. If a 2012 household was found, some of its members may have left to form a split household (for example, young persons may marry and leave their natal household to form a new household). Although fieldworkers collected as much information as possible from the original 2012 household (as located in 2018) to locate split households, sometimes split households could not be located. We refer to the inability to locate the individual(s) in 2018 who were part of a 2012 household as Type II attrition; the main household was found but a split household was not. In this section, we describe and then model these two types of attrition. We then use these models to estimate the predicted probability of each type of attrition as a function of 2012 observable characteristics and use these probabilities to create weights to correct for attrition, as detailed in Section 3.

\subsubsection{Attrition of entire households (Type I attrition)}

Table 2 presents the status of the households from the 2012 wave in 2018. There were 12,060 households fielded in 2012. Of these, 10,042 (83.3\%) were located in 2018; they may have been

6 The repetition of enumeration in fielding did allow us to determine that 208 individuals had naturally attrited, i.e., died, migrated, or moved to group housing between enumeration and fielding (Krafft and Assaad, 2021a). 
Table 2 Status of 2012 households in 2018

\begin{tabular}{lrc}
\hline & Number & Percentage \\
\hline Initial households & 12,060 & 100.0 \\
Household located & 10,042 & 83.3 \\
Natural attrition & 252 & 2.1 \\
Household died out & 188 & 1.6 \\
Household left the country & 64 & 0.5 \\
Type I attrition & 1,766 & 14.6 \\
Household refused & 204 & 1.7 \\
Household found but not completed & 291 & 2.4 \\
Household not found & 1,271 & 10.5 \\
Type I attrition rate & & 15.0 \\
\hline
\end{tabular}

Source: Authors' calculations based on ELMPS 2012 and 2018.

ELMPS, Egypt Labor Market Panel Survey.

found in a different location or with a different composition, but at least one of their 2012 members was found. Among the 2012 households that were not located in 2018, data were collected from neighbors, if possible, on the disposition of the household, including whether and where they moved (if they moved), so they could be tracked. For 188 households, we know that the entire household died out. For another 64 households, we know that the entire household left the country. ${ }^{7}$ We refer to these two groups of households (252 or 2.1\% of the original 2012 households) as having naturally attrited. If we had been drawing a completely new sample, they could not have been included. Thus, these households are excluded from the sample when modeling attrition or calculating the Type I attrition rate (the 2012-2018 household attrition rate).

Type I attrition occurs when a 2012 household was not found or refused to respond in 2018, since (to our knowledge) they should have been included in the sample and were not. Some 204 households refused (1.7\% of the initial households) and a further 291 were found but could not be successfully completed (2.4\%). A further 1,271 households were not found at all (10.5\% of original 2012 households). Together, 1,766 households attrited. After excluding natural attrition, this results in a Type I attrition rate of $15.0 \%$.

This $15.0 \%$ Type I attrition rate represents an improvement compared with previous rounds of the ELMPS and JLMPS. For example, in ELMPS 2006 the Type I attrition rate was 23.5\%, in ELMPS 2012 it was 17.3\%, and in JLMPS 2016 it was 38.1\% (Assaad and Krafft, 2013; Assaad and Roushdy, 2009; Krafft and Assaad, 2021a). Besides the dedication of the fielding team, we attribute this lower rate of attrition to integrating the enumeration step with the main fieldwork, since in both past JLMPS and ELMPSs additional households were lost between enumeration and fielding (Assaad and Krafft, 2013; Krafft and Assaad, 2021a).

We present our model of Type I attrition in Table 3. We present odds ratios from a logit model that includes 2012 characteristics (since only households who did not attrite would have 2018 characteristics $)^{8}$ for the 2012 household sample, excluding households that experienced natural attrition. Characteristics include household composition, location (governorate fully

7 Or left the sample frame, if they moved to the Frontier governorates.

8 Since we can only use 2012 characteristics to be able to model attrition, we cannot account for any migration that may have occurred between 2012 and 2018 in our model. 
Table 3 Type I attrition logit model: odds ratios for probability of attrition

\begin{tabular}{|c|c|}
\hline \multicolumn{2}{|c|}{ Number of household members } \\
\hline \multirow[t]{2}{*}{ No. of Children 0-5 in $\mathrm{HH}$} & 0.938 \\
\hline & $(0.037)$ \\
\hline \multirow[t]{2}{*}{ No. of Children 6-14 in HH } & $0.859^{\star \star \star}$ \\
\hline & $(0.032)$ \\
\hline \multirow[t]{2}{*}{ No. of Males $15-64$ in $\mathrm{HH}$} & $0.833^{\star \star \star}$ \\
\hline & $(0.040)$ \\
\hline \multirow[t]{2}{*}{ No. of Females 15-64 in HH } & 0.918 \\
\hline & $(0.045)$ \\
\hline \multirow[t]{2}{*}{ No. of Males $65+$ in $\mathrm{HH}$} & $0.595^{\star \star}$ \\
\hline & $(0.095)$ \\
\hline \multirow[t]{2}{*}{ No. of Females $65+$ in $\mathrm{HH}$} & $0.693^{\star \star}$ \\
\hline & $(0.090)$ \\
\hline \multicolumn{2}{|c|}{ Single sex households (mixed sex omit.) } \\
\hline \multirow[t]{2}{*}{ All male } & 1.543 \\
\hline & $(0.454)$ \\
\hline \multirow[t]{2}{*}{ All female } & $1.407^{\star}$ \\
\hline & $(0.209)$ \\
\hline \multicolumn{2}{|c|}{ Governorate (Cairo (urban) omit.) } \\
\hline \multirow[t]{2}{*}{ Alex. \# urban } & $1.811^{\star \star \star}$ \\
\hline & $(0.197)$ \\
\hline \multirow[t]{2}{*}{ Port-Said \# urban } & $0.310^{\star \star}$ \\
\hline & $(0.114)$ \\
\hline \multirow[t]{2}{*}{ Suez \# urban } & 0.740 \\
\hline & $(0.156)$ \\
\hline \multirow[t]{2}{*}{ Damietta \# urban } & 0.654 \\
\hline & $(0.179)$ \\
\hline \multirow[t]{2}{*}{ Damietta \# rural } & $0.517^{\star \star \star}$ \\
\hline & $(0.098)$ \\
\hline \multirow[t]{2}{*}{ Dakahlia \# urban } & $0.151^{\star \star \star}$ \\
\hline & $(0.043)$ \\
\hline \multirow[t]{2}{*}{ Dakahlia \# rural } & $0.181^{\star \star \star}$ \\
\hline & $(0.039)$ \\
\hline \multirow[t]{2}{*}{ Sharkia \# urban } & $0.628^{\star}$ \\
\hline & $(0.114)$ \\
\hline \multirow[t]{2}{*}{ Sharkia \# rural } & $0.225^{\star \star \star}$ \\
\hline & $(0.047)$ \\
\hline \multirow[t]{2}{*}{ Kalyoubia \# urban } & 0.966 \\
\hline & $(0.168)$ \\
\hline \multirow[t]{2}{*}{ Kalyoubia \# rural } & $0.484^{\star \star \star}$ \\
\hline & $(0.086)$ \\
\hline \multirow[t]{2}{*}{ Kafr-Elsheikh \# urban } & $0.414^{\star \star \star}$ \\
\hline & $(0.101)$ \\
\hline
\end{tabular}


Table 3 Continued

\begin{tabular}{|c|c|}
\hline Number of household & \\
\hline Kafr-Elsheikh \# rural & $0.251^{\star \star \star}$ \\
\hline & $(0.054)$ \\
\hline Gharbia \# urban & 0.830 \\
\hline & $(0.145)$ \\
\hline Gharbia \# rural & $0.219^{\star \star \star}$ \\
\hline & $(0.048)$ \\
\hline Menoufia \# urban & $0.487^{\star \star}$ \\
\hline & $(0.117)$ \\
\hline Menoufia \# rural & $0.154^{\star \star \star}$ \\
\hline & $(0.052)$ \\
\hline Behera \# urban & $0.287^{\star \star \star}$ \\
\hline & $(0.074)$ \\
\hline Behera \# rural & $0.312^{\star \star \star}$ \\
\hline & $(0.063)$ \\
\hline Ismailia \# urban & $0.658^{*}$ \\
\hline & $(0.131)$ \\
\hline Ismailia \# rural & $0.223^{\star \star \star}$ \\
\hline & $(0.052)$ \\
\hline Giza \# urban & 0.787 \\
\hline & $(0.123)$ \\
\hline Giza \# rural & $0.657^{\star}$ \\
\hline & $(0.117)$ \\
\hline Beni-Suef \# urban & $0.592^{\star \star}$ \\
\hline & $(0.117)$ \\
\hline Beni-Suef \# rural & $0.647^{\star}$ \\
\hline & $(0.118)$ \\
\hline Fayoum \# urban & 0.681 \\
\hline & $(0.135)$ \\
\hline Fayoum \# rural & $0.179^{\star \star \star}$ \\
\hline & $(0.056)$ \\
\hline Menia \# urban & $0.314^{\star \star \star}$ \\
\hline & $(0.079)$ \\
\hline Menia \# rural & $0.264^{\star \star \star}$ \\
\hline & $(0.056)$ \\
\hline Asyout \# urban & $0.454^{\star \star \star}$ \\
\hline & $(0.089)$ \\
\hline Asyout \# rural & $0.417^{\star \star \star}$ \\
\hline & $(0.083)$ \\
\hline Suhag \# urban & $0.556^{\star \star}$ \\
\hline & $(0.114)$ \\
\hline Suhag \# rural & $0.137^{\star \star \star}$ \\
\hline & $(0.036)$ \\
\hline
\end{tabular}


Table 3 Continued

\begin{tabular}{|c|c|}
\hline \multicolumn{2}{|c|}{ Number of household members } \\
\hline \multirow[t]{2}{*}{ Qena \# urban } & $0.561^{\star}$ \\
\hline & $(0.128)$ \\
\hline \multirow[t]{2}{*}{ Qena \# rural } & $0.348^{\star \star \star}$ \\
\hline & $(0.073)$ \\
\hline \multirow[t]{2}{*}{ Aswan \# urban } & $0.404^{\star \star \star}$ \\
\hline & $(0.099)$ \\
\hline \multirow[t]{2}{*}{ Aswan \# rural } & $0.244^{\star \star \star}$ \\
\hline & $(0.072)$ \\
\hline \multirow[t]{2}{*}{ Luxur \# urban } & 0.738 \\
\hline & $(0.266)$ \\
\hline \multirow[t]{2}{*}{ Luxur \# rural } & 0.427 \\
\hline & $(0.192)$ \\
\hline \multicolumn{2}{|c|}{ Housing type (own or benefit omit.) } \\
\hline \multirow[t]{2}{*}{ Old rent } & $1.352^{\star \star \star}$ \\
\hline & $(0.104)$ \\
\hline \multirow[t]{2}{*}{ New rent } & $2.636^{\star \star \star}$ \\
\hline & $(0.272)$ \\
\hline \multicolumn{2}{|l|}{ Head age (<25 omit.) } \\
\hline \multirow[t]{2}{*}{$25-34$} & 0.956 \\
\hline & $(0.145)$ \\
\hline \multirow[t]{2}{*}{$35-44$} & 1.012 \\
\hline & $(0.163)$ \\
\hline \multirow[t]{2}{*}{$45-54$} & 0.799 \\
\hline & $(0.138)$ \\
\hline \multirow[t]{2}{*}{$55+$} & $0.642^{\star}$ \\
\hline & $(0.114)$ \\
\hline \multicolumn{2}{|l|}{ Head sex (male omit.) } \\
\hline \multirow[t]{2}{*}{ Female } & 0.907 \\
\hline & $(0.160)$ \\
\hline \multicolumn{2}{|c|}{ Head marital stat. (married omit.) } \\
\hline \multirow[t]{2}{*}{ Single } & $0.392^{\star \star}$ \\
\hline & $(0.141)$ \\
\hline \multirow[t]{2}{*}{ Divorced } & 0.608 \\
\hline & $(0.265)$ \\
\hline \multirow[t]{2}{*}{ Widow(er) } & 1.177 \\
\hline & $(0.306)$ \\
\hline \multicolumn{2}{|c|}{ Head marital stat. and sex int. } \\
\hline \multirow[t]{2}{*}{ Female \# Single } & 2.643 \\
\hline & $(1.384)$ \\
\hline \multirow[t]{2}{*}{ Female \# Divorced } & 2.210 \\
\hline & $(1.140)$ \\
\hline \multirow[t]{2}{*}{ Female \# Widow(er) } & 0.778 \\
\hline & $(0.246)$ \\
\hline
\end{tabular}


Table 3 Continued

\begin{tabular}{|c|c|}
\hline Number of household members & \\
\hline \multicolumn{2}{|l|}{ Head education (illit. omit.) } \\
\hline \multirow[t]{2}{*}{ Reads \& Writes } & 1.049 \\
\hline & $(0.142)$ \\
\hline \multirow[t]{2}{*}{ Less than Intermediate } & 1.037 \\
\hline & $(0.100)$ \\
\hline \multirow[t]{2}{*}{ Intermediate } & 1.075 \\
\hline & $(0.100)$ \\
\hline \multirow[t]{2}{*}{ Above Intermediate } & 0.936 \\
\hline & $(0.154)$ \\
\hline \multirow[t]{2}{*}{ University } & $1.326^{\star}$ \\
\hline & $(0.146)$ \\
\hline \multicolumn{2}{|c|}{ Head labor mkt. status (Government employee omit.) } \\
\hline \multirow[t]{2}{*}{ Out of manpower } & $1.589^{\star \star}$ \\
\hline & $(0.257)$ \\
\hline \multirow[t]{2}{*}{ Out of labor force } & 0.974 \\
\hline & $(0.120)$ \\
\hline \multirow[t]{2}{*}{ Unemployed. } & 0.848 \\
\hline & $(0.191)$ \\
\hline \multirow[t]{2}{*}{ Public enterp. } & 1.133 \\
\hline & $(0.169)$ \\
\hline \multirow[t]{2}{*}{ Priv. formal wage } & 1.018 \\
\hline & $(0.113)$ \\
\hline \multirow[t]{2}{*}{ Priv. inf. reg. wage } & 1.065 \\
\hline & $(0.118)$ \\
\hline \multirow[t]{2}{*}{ Priv. irreg. wage } & 0.872 \\
\hline & $(0.104)$ \\
\hline \multirow[t]{2}{*}{ Employer } & 0.811 \\
\hline & $(0.096)$ \\
\hline \multirow[t]{2}{*}{ Self-emp./UFW ag. } & 0.605 \\
\hline & $(0.181)$ \\
\hline \multirow[t]{2}{*}{ Self-emp./UFW non-ag. } & 0.886 \\
\hline & $(0.111)$ \\
\hline \multicolumn{2}{|l|}{ Wealth quintile (poorest omit.) } \\
\hline \multirow[t]{2}{*}{ Second } & 0.896 \\
\hline & $(0.090)$ \\
\hline \multirow[t]{2}{*}{ Third } & 0.883 \\
\hline & $(0.092)$ \\
\hline \multirow[t]{2}{*}{ Fourth } & 1.045 \\
\hline & $(0.111)$ \\
\hline \multirow[t]{2}{*}{ Richest } & 1.176 \\
\hline & $(0.136)$ \\
\hline
\end{tabular}


Table 3 Continued

\begin{tabular}{lc}
\hline Number of household members & \\
\hline Constant & $0.564^{\star}$ \\
& $(0.129)$ \\
\hline Pseudo R-sq. & 0.122 \\
$\mathbf{N}$ (households) & 11808 \\
\hline Source: Authors' calculations based on ELMPS 2012 and 2018. \\
Notes: ${ }^{\star} p<0.05 ;{ }^{\star *} p<0.01 ;{ }^{\star * *} p<0.001$. ELMPS, Egypt Labor Market Panel Survey.
\end{tabular}

interacted with urban/rural), housing type, and 2012 household head characteristics (age, sex, marital status, sex-marital status interaction, education, and labor market status), and household wealth quintile. Importantly, the model indicates the extent to which attrition was random vs. related to observable household characteristics (and thus suggests, although it does not calculate, the relationship with unobservables as well). Overall, the pseudo-R-squared of the model is moderate, at $12.2 \%$, indicating that while the 2012 household characteristics do predict Type I attrition, they do so only to a modest extent. As a point of comparison, the JLMPS 2016 Type I model pseudo-R-squared was 14.7\% (Krafft and Assaad, 2021a).

Examining the specific 2012 characteristics which were predictors of attrition, having more children aged (as of 2012) 6-14 years, having more men aged 15-64 years as well as 65+, and having more women aged 65+ significantly decreased the odds of Type I attrition. Single sex, compared with mixed sex households, had significantly higher odds of attrition with similar odds ratios for all men and all women, but only the odds ratio for all women was significant. There were significant geographic differences compared to (all-urban) Cairo; with the exception of significantly higher odds of attrition in (all-urban) Alexandria, all other governorate-location combinations had lower, often significantly so, odds of attrition. Compared with households that owned their house, or had it as a benefit, in 2012, those who rented had significantly higher odds of attrition, particularly so for "new rent" (non-rent-controlled) housing contracts.

Turning to household head characteristics, households with heads 55+ were significantly less likely to attrite compared with households with heads $<25$, but there were no significant differences for other age groups. There were no significant differences for female-headed households compared with male-headed ones. Households headed by single individuals were significantly less likely to attrite than those for married individuals, although this was true primarily for the reference category of men; the female and single as well as female and divorced interactions resulted in an increase in the odds of attrition, although not in a statistically significant manner because of the small number of such households. Compared to households with illiterate heads, those with most other levels of education had a similar probability of attrition, with the exception of households with university-educated heads, who were more likely to attrite. Most head labor market statuses were not significantly different from the reference, government employee category. The exception was a significantly higher probability of attrition for heads who were out of the manpower basis, meaning heads who were either disabled or $\geq 65$ years.

\subsubsection{Attrition of split households (Type II attrition)}

Among the 2012 households that were found, some individuals who were present in 2012 may not have been present in 2018. They may have been absent for various reasons, including 
Table 4 Status of individuals and split households in 2018, conditional on 2012 household being found

\begin{tabular}{|c|c|c|}
\hline & Number & Percentage \\
\hline Individuals present in 2012 in original households found in 2018 & 42,340 & 100.0 \\
\hline Individuals still in original households in 2018 & 34,325 & 81.1 \\
\hline Individuals no longer in original households in 2018 & 8,015 & 18.9 \\
\hline Natural attrition through death and migration or leaving sample frame & 2,171 & 5.1 \\
\hline Individuals known to have died & 1,497 & 3.5 \\
\hline Individuals who emigrated or left for a gov. outside scope of survey & 552 & 1.3 \\
\hline Individuals who moved to group housing & 122 & 0.3 \\
\hline Individual splits to form households within Egypt & 5,844 & 13.8 \\
\hline Potential split households (individuals who split together) & 4,598 & \\
\hline Split households found & 3,751 & 81.6 \\
\hline Split households not found (attrited) & 847 & 18.4 \\
\hline Type II attrition rate & & 18.4 \\
\hline Individuals from 2012 in split households found & 4,828 & 82.6 \\
\hline Individuals from 2012 in split households not found (attrited) & 1,016 & 17.4 \\
\hline Total individuals from 2012 who were found & 39,153 & \\
\hline
\end{tabular}

Source: Authors' calculations based on ELMPS 2012 and 2018.

ELMPS, Egypt Labor Market Panel Survey.

splitting from their original household to form a new household. Table 4 shows the status of individuals who were present in 2012 households, whose 2012 household was found. Of the 49,186 individuals present in 2012, 42,340 were in households that were found in 2018. However, only 34,325 of those individuals were still in their 2012 households in 2018. Of the 8,015 individuals not in their 2012 households, 2,171 were absent due to natural attrition; 1,497 died, 552 emigrated either outside the governorates covered or outside the country, and 122 moved to group housing and were thus outside the sampling frame. The remaining 5,844 individuals split to form households within Egypt. We attempted to track all of these individuals who split from their 2012 households and formed new households.

When individuals split to form new households, sometimes they did so together, for example, if two brothers left their natal household in Aswan to come work in Cairo and shared a flat. Since our sampling unit was households, we identified the "split households" composed of individuals who split together. The 5,844 individuals who split made up 4,598 split households, meaning that, on average, each split involved 1.27 individuals leaving together. Of these split households, 3,751 were found and 847 were not, resulting in a Type II attrition rate (attrition rate of split households) of $18.4 \%$. This is a substantial improvement over the $30.3 \%$ rate of ELMPS 2012 or the 50.5\% rate in JLMPS 2016 (Assaad and Krafft, 2013; Krafft and Assaad, 2021a). Even more so than in the case of Type I attrition, we attribute this reduction in the Type II attrition rate to eliminating enumeration as a separate step in fieldwork, as we previously lost many splits between enumeration and fielding.

We present in Table 5 odds ratios from a logit model of Type II attrition, estimated for the sample of 4,598 split households. The pseudo-R-squared for the Type II model, at $22.3 \%$, is higher than for the Type I attrition model, indicating that the loss of split households is less random than households overall. The determinants we include are characteristics of the 2012 
Table 5 Type II attrition logit model: odds ratios for probability of attrition

\begin{tabular}{|c|c|}
\hline \multicolumn{2}{|c|}{ Number of household members } \\
\hline \multirow[t]{2}{*}{ No. of Children 0-5 in $\mathrm{HH}$} & $0.088^{\star \star \star}$ \\
\hline & $(0.047)$ \\
\hline \multirow[t]{2}{*}{ No. of Children 6-14 in HH } & $0.002^{\star \star \star}$ \\
\hline & $(0.002)$ \\
\hline \multirow[t]{2}{*}{ No. of Males $15-64$ in $\mathrm{HH}$} & $0.009^{\star * \star}$ \\
\hline & $(0.007)$ \\
\hline \multirow[t]{2}{*}{ No. of Females 15-64 in HH } & $0.032^{\star \star \star}$ \\
\hline & $(0.021)$ \\
\hline \multirow[t]{2}{*}{ No. of Males $65+$ in $\mathrm{HH}$} & $0.038^{\star \star}$ \\
\hline & $(0.047)$ \\
\hline \multirow[t]{2}{*}{ No. of Females $65+$ in $\mathrm{HH}$} & $0.007^{\star \star \star}$ \\
\hline & $(0.009)$ \\
\hline \multicolumn{2}{|c|}{ Governorate (Cairo (urban) omit.) } \\
\hline \multirow[t]{2}{*}{ Alex. \# urban } & $0.210^{\star \star \star}$ \\
\hline & $(0.053)$ \\
\hline \multirow[t]{2}{*}{ Port-Said \# urban } & $0.012^{\star \star \star}$ \\
\hline & $(0.012)$ \\
\hline \multirow[t]{2}{*}{ Suez \# urban } & $0.028^{\star \star \star}$ \\
\hline & $(0.015)$ \\
\hline \multirow[t]{2}{*}{ Damietta \# urban } & $0.050^{\star \star \star}$ \\
\hline & $(0.032)$ \\
\hline \multirow[t]{2}{*}{ Damietta \# rural } & $0.083^{\star \star \star}$ \\
\hline & $(0.034)$ \\
\hline \multirow[t]{2}{*}{ Dakahlia \# urban } & $0.069^{\star \star \star}$ \\
\hline & $(0.027)$ \\
\hline \multirow[t]{2}{*}{ Dakahlia \# rural } & $0.053^{\star \star \star}$ \\
\hline & $(0.016)$ \\
\hline \multirow[t]{2}{*}{ Sharkia \# urban } & $0.122^{\star \star \star}$ \\
\hline & $(0.045)$ \\
\hline \multirow[t]{2}{*}{ Sharkia \# rural } & $0.100^{\star \star \star}$ \\
\hline & $(0.028)$ \\
\hline \multirow[t]{2}{*}{ Kalyoubia \# urban } & $0.300^{\star \star}$ \\
\hline & $(0.111)$ \\
\hline \multirow[t]{2}{*}{ Kalyoubia \# rural } & $0.094^{\star \star \star}$ \\
\hline & $(0.032)$ \\
\hline \multirow[t]{2}{*}{ Kafr-Elsheikh \# urban } & $0.049^{\star \star \star}$ \\
\hline & $(0.026)$ \\
\hline \multirow[t]{2}{*}{ Kafr-Elsheikh \# rural } & $0.050^{\star \star \star}$ \\
\hline & $(0.017)$ \\
\hline \multirow[t]{2}{*}{ Gharbia \# urban } & $0.172^{\star \star \star}$ \\
\hline & $(0.058)$ \\
\hline
\end{tabular}


Table 5 Continued

\begin{tabular}{|c|c|}
\hline \multicolumn{2}{|c|}{ Number of household members } \\
\hline \multirow[t]{2}{*}{ Gharbia \# rural } & $0.098^{\star \star \star}$ \\
\hline & $(0.028)$ \\
\hline \multirow[t]{2}{*}{ Menoufia \# urban } & $0.072^{\star \star \star}$ \\
\hline & $(0.032)$ \\
\hline \multirow[t]{2}{*}{ Menoufia \# rural } & $0.082^{\star \star \star}$ \\
\hline & $(0.033)$ \\
\hline \multirow[t]{2}{*}{ Behera \# urban } & $0.086^{\star \star \star}$ \\
\hline & $(0.036)$ \\
\hline \multirow[t]{2}{*}{ Behera \# rural } & $0.083^{\star \star \star}$ \\
\hline & $(0.026)$ \\
\hline \multirow[t]{2}{*}{ Ismailia \# urban } & $0.123^{\star \star \star}$ \\
\hline & $(0.043)$ \\
\hline \multirow[t]{2}{*}{ Ismailia \# rural } & $0.111^{\star \star \star}$ \\
\hline & $(0.035)$ \\
\hline \multirow[t]{2}{*}{ Giza \# urban } & $0.245^{\star \star \star}$ \\
\hline & $(0.071)$ \\
\hline \multirow[t]{2}{*}{ Giza \# rural } & $0.348^{\star \star \star}$ \\
\hline & $(0.102)$ \\
\hline \multirow[t]{2}{*}{ Beni-Suef \# urban } & $0.086^{\star \star \star}$ \\
\hline & $(0.034)$ \\
\hline \multirow[t]{2}{*}{ Beni-Suef \# rural } & $0.161^{\star \star \star}$ \\
\hline & $(0.044)$ \\
\hline \multirow[t]{2}{*}{ Fayoum \# urban } & $0.015^{\star \star \star}$ \\
\hline & $(0.011)$ \\
\hline \multirow[t]{2}{*}{ Fayoum \# rural } & $0.112^{\star \star \star}$ \\
\hline & $(0.034)$ \\
\hline \multirow[t]{2}{*}{ Menia \# urban } & $0.072^{\star \star \star}$ \\
\hline & $(0.028)$ \\
\hline \multirow[t]{2}{*}{ Menia \# rural } & $0.061^{\star \star \star}$ \\
\hline & $(0.017)$ \\
\hline \multirow[t]{2}{*}{ Asyout \# urban } & $0.095^{\star \star \star}$ \\
\hline & $(0.030)$ \\
\hline \multirow[t]{2}{*}{ Asyout \# rural } & $0.107^{\star \star \star}$ \\
\hline & $(0.029)$ \\
\hline \multirow[t]{2}{*}{ Suhag \# urban } & $0.050^{\star \star \star}$ \\
\hline & $(0.021)$ \\
\hline \multirow[t]{2}{*}{ Suhag \# rural } & $0.035^{\star \star \star}$ \\
\hline & $(0.011)$ \\
\hline \multirow[t]{2}{*}{ Qena \# urban } & $0.106^{\star \star \star}$ \\
\hline & $(0.040)$ \\
\hline \multirow[t]{2}{*}{ Qena \# rural } & $0.086^{\star \star \star}$ \\
\hline & $(0.023)$ \\
\hline
\end{tabular}


Table 5 Continued

\begin{tabular}{|c|c|}
\hline \multicolumn{2}{|l|}{ Number of household members } \\
\hline \multirow[t]{2}{*}{ Aswan \# urban } & $0.071^{\star \star \star}$ \\
\hline & $(0.027)$ \\
\hline \multirow[t]{2}{*}{ Aswan \# rural } & $0.074^{\star \star \star}$ \\
\hline & $(0.026)$ \\
\hline \multirow[t]{2}{*}{ Luxor \# urban } & $0.199^{\star}$ \\
\hline & $(0.146)$ \\
\hline \multirow[t]{2}{*}{ Luxor \# rural } & $0.125^{\star \star \star}$ \\
\hline & $(0.069)$ \\
\hline \multicolumn{2}{|c|}{ Housing type (own or benefit omit.) } \\
\hline \multirow[t]{2}{*}{ Old rent } & 1.036 \\
\hline & $(0.159)$ \\
\hline \multirow[t]{2}{*}{ New rent } & $3.021^{\star \star}$ \\
\hline & $(1.190)$ \\
\hline \multicolumn{2}{|l|}{ Head age (<15 omit.) } \\
\hline \multirow[t]{2}{*}{$15-24$} & $0.075^{\star}$ \\
\hline & $(0.099)$ \\
\hline \multirow[t]{2}{*}{$25-34$} & 0.079 \\
\hline & $(0.104)$ \\
\hline \multirow[t]{2}{*}{$35-44$} & 0.115 \\
\hline & $(0.151)$ \\
\hline \multirow[t]{2}{*}{$45+$} & 0.127 \\
\hline & $(0.171)$ \\
\hline \multicolumn{2}{|l|}{ Head sex (male omit.) } \\
\hline \multirow[t]{2}{*}{ Female } & $0.269^{\star}$ \\
\hline & $(0.147)$ \\
\hline \multicolumn{2}{|l|}{ Head marital stat. (married omit.) } \\
\hline \multirow[t]{2}{*}{ Single } & $0.122^{\star \star \star}$ \\
\hline & $(0.033)$ \\
\hline \multirow[t]{2}{*}{ Divorced/Widow(er) } & $0.293^{\star}$ \\
\hline & $(0.175)$ \\
\hline \multicolumn{2}{|l|}{ Head marital stat. and sex int. } \\
\hline \multirow[t]{2}{*}{ Female \# Single } & 1.640 \\
\hline & $(0.526)$ \\
\hline \multirow[t]{2}{*}{ Female \# Divorced/Widow(er) } & 0.837 \\
\hline & $(0.587)$ \\
\hline \multicolumn{2}{|l|}{ Head education (illit. omit.) } \\
\hline \multirow[t]{2}{*}{ Reads \& Writes } & 1.355 \\
\hline & $(0.350)$ \\
\hline \multirow[t]{2}{*}{ Less than Intermediate } & 1.131 \\
\hline & $(0.193)$ \\
\hline \multirow[t]{2}{*}{ Intermediate } & 1.142 \\
\hline & $(0.201)$ \\
\hline
\end{tabular}


Table 5 Continued

\begin{tabular}{|c|c|}
\hline \multicolumn{2}{|c|}{ Number of household members } \\
\hline \multirow[t]{2}{*}{ Above Intermediate } & 1.811 \\
\hline & $(0.590)$ \\
\hline \multirow[t]{2}{*}{ University } & 1.498 \\
\hline & $(0.334)$ \\
\hline \multicolumn{2}{|c|}{ Head labor mkt. status (Government employee omit.) } \\
\hline \multirow[t]{2}{*}{ Out of manpower } & 1.042 \\
\hline & $(0.832)$ \\
\hline \multirow[t]{2}{*}{ Out of labor force } & 1.546 \\
\hline & $(0.377)$ \\
\hline \multirow[t]{2}{*}{ Unemployed. } & 1.668 \\
\hline & $(0.444)$ \\
\hline \multirow[t]{2}{*}{ Public enterp. } & 1.028 \\
\hline & $(0.498)$ \\
\hline \multirow[t]{2}{*}{ Priv. formal wage } & 1.755 \\
\hline & $(0.526)$ \\
\hline \multirow[t]{2}{*}{ Priv. inf. reg. wage } & 1.618 \\
\hline & $(0.432)$ \\
\hline \multirow[t]{2}{*}{ Priv. irreg. wage } & 1.524 \\
\hline & $(0.432)$ \\
\hline \multirow[t]{2}{*}{ Employer } & 1.612 \\
\hline & $(0.645)$ \\
\hline \multirow[t]{2}{*}{ Self-emp./UFW ag. } & 0.677 \\
\hline & $(0.274)$ \\
\hline \multirow[t]{2}{*}{ Self-emp./UFW non-ag. } & 1.203 \\
\hline & $(0.408)$ \\
\hline \multicolumn{2}{|c|}{ Wealth quintile (poorest omit.) } \\
\hline \multirow[t]{2}{*}{ Second } & 1.278 \\
\hline & $(0.174)$ \\
\hline \multirow[t]{2}{*}{ Third } & 1.122 \\
\hline & $(0.163)$ \\
\hline \multirow[t]{2}{*}{ Fourth } & $1.436^{\star}$ \\
\hline & $(0.223)$ \\
\hline \multirow[t]{2}{*}{ Richest } & $2.125^{\star \star \star}$ \\
\hline & $(0.363)$ \\
\hline \multirow[t]{2}{*}{ Constant } & $7218.760^{\star \star \star}$ \\
\hline & $(8790.485)$ \\
\hline Pseudo R-sq. & 0.223 \\
\hline N (households) & 4598 \\
\hline
\end{tabular}

Source: Authors' calculations based on ELMPS 2012 and 2018.

Notes: ${ }^{\star} p<0.05 ;{ }^{\star \star} p<0.01$; ${ }^{\star \star \star} p<0.001$. For 46 split households, failures were completely determined. ELMPS, Egypt Labor Market Panel Survey. 
households as well as those of the "head" (or most senior member) of the split household. While most "split households" were made up of one individual, the presence of additional household members of all ages and both sexes predicted a significantly lower probability of attrition. Compared to those that were in (urban) Cairo, split households were significantly less likely to attrite everywhere else. As in the case of Type I attrition, splits from households living in "new rent" housing, compared to owned housing, were significantly more likely to attrite. Compared with heads who were $<15$ years in 2012 (so would have been under 21 in 2018), those 15-24 years in 2012 were significantly less likely to attrite. Other age groups were not significantly more likely to attrite than the reference category. Female-headed households (mostly single women) were significantly less likely to attrite than male-headed ones. Those split households whose heads were single or divorced/widowed were significantly less likely to attrite than those who were married in 2012. There were no significant interactions between the sex of the split household head and their marital status. There were also no significant differences in attrition by split household head education or labor market status in 2012. There were significant wealth interactions, splits from households that were in the fourth and especially richest quintile were more likely to attrite. Overall, Type II attrition appears to be driven more by demographic and geographic factors than by education or labor market characteristics.

\subsection{Panel sample}

The ELMPS waves track individuals over two decades, including a large number of individuals who were in multiple waves. Table 6 presents the sample, with an observation being a unique individual, and shows the number and percentage of individuals in different combinations of waves, e.g., in 1998 and 2006 and 2012 and 2018 (i.e., in all waves) or in 2018 only (i.e., 2018 refresher). There were 10,145 individuals tracked from 1998 through 2019 (out of 23,997 in the 1998 wave). Since refresher samples were added in each wave, the number of individuals in multiple waves increases over time. For instance, there were 12,756 individuals in 2006 and

Table 6 Individuals present in various combinations of waves, 1998-2018

\begin{tabular}{lcc}
\hline Waves present & Number & Percentage \\
\hline In 1998 \& 2006 \& 2012 & 3,073 & 3.6 \\
In 1998 \& 2006 & 4,143 & 4.8 \\
In 1998 only & 6,636 & 7.7 \\
In 2006 \& 2012 & 2,796 & 3.2 \\
In 2006 only & 4,227 & 4.9 \\
In 2012 only & 4,164 & 4.8 \\
In 1998 \& 2006 \& 2012 \& 2018 & 10,145 & 11.8 \\
In 2006 \& 2012 \& 2018 & 12,756 & 14.8 \\
In 2012 \& 2018 & 16,252 & 18.8 \\
In 2018 only & 22,078 & 25.6 \\
\hline Total & 86,270 & 100.0 \\
\hline Source: Author's calculations based
\end{tabular}

Source: Author's calculations based on ELMPS 1998-2018.

Notes: An individual appears only once, in one category.

ELMPS, Egypt Labor Market Panel Survey. 
2012 and 2018 (but not in 1998), who can be analyzed as a 2006-2018 panel along with the 10,145 individuals in the 1998-2018 panel.

\subsection{The 2018 refresher sample}

In addition to tracking the households that were present in the 2012 round into 2018, the ELMPS 2018 added a refresher sample. The refresher sample was focused on over-sampling the 1,000 poorest villages in Egypt, as a key theme of the 2018 wave was economic vulnerability. A poverty map created by CAPMAS in 2013 with the assistance of the World Bank and UNDP was used to identify the 1,000 poorest villages. ${ }^{9}$ A stratified random sample was used, with strata defined by governorate (the first level of administrative geography in Egypt), urban/rural location, and within rural areas, poor (i.e., among the 1,000 poorest villages) vs. non-poor.

Table 7 presents the distribution of the refresher sample clusters across these various strata. It is important to note that the 1,000 poorest villages were all in rural areas and only

Table 7 Refresher sample clusters by governorate, urban/rural location, and poor vs. non-poor

\begin{tabular}{|c|c|c|c|c|c|c|c|c|c|}
\hline \multirow[b]{2}{*}{ Governorate } & \multicolumn{3}{|c|}{ Urban } & \multicolumn{3}{|c|}{ Rural } & \multicolumn{3}{|c|}{ Total } \\
\hline & Poor & Non-poor & Total & Poor & Non-poor & Total & Poor & Non-poor & Total \\
\hline Cairo & & 10 & 10 & & & & & 10 & 10 \\
\hline Alexandria & & 7 & 7 & & & & & 7 & 7 \\
\hline Port Said & & 1 & 1 & & & & & 1 & 1 \\
\hline Suez & & 1 & 1 & & & & & 1 & 1 \\
\hline Damietta & & 1 & 1 & & 1 & 1 & & 2 & 2 \\
\hline Dakhalia & & 5 & 5 & 4 & 3 & 7 & 4 & 8 & 12 \\
\hline Sharkia & & 4 & 4 & & 3 & 3 & & 7 & 7 \\
\hline Kalyoubia & & 4 & 4 & 4 & 1 & 5 & 4 & 5 & 9 \\
\hline Kafr-Elsheikh & & 1 & 1 & & 1 & 1 & & 2 & 2 \\
\hline Gharbia & & 2 & 2 & & 2 & 2 & & 4 & 4 \\
\hline Menoufia & & 1 & 1 & 4 & 2 & 6 & 4 & 3 & 7 \\
\hline Behera & & 2 & 2 & 14 & 2 & 16 & 14 & 4 & 18 \\
\hline Ismailia & & 1 & 1 & & 1 & 1 & & 2 & 2 \\
\hline Giza & & 7 & 7 & 8 & 2 & 10 & 8 & 9 & 17 \\
\hline Beni-Suef & & 1 & 1 & 6 & 1 & 7 & 6 & 2 & 8 \\
\hline Fayoum & & 1 & 1 & 1 & 2 & 3 & 1 & 3 & 4 \\
\hline Menia & & 1 & 1 & 2 & 3 & 5 & 2 & 4 & 6 \\
\hline Asyout & & 3 & 3 & 19 & 4 & 23 & 19 & 7 & 26 \\
\hline Suhag & & 2 & 2 & 19 & 4 & 23 & 19 & 6 & 25 \\
\hline Qena & & 2 & 2 & 15 & 5 & 20 & 15 & 7 & 22 \\
\hline Aswan & & 2 & 2 & 3 & 2 & 5 & 3 & 4 & 7 \\
\hline Luxor & & 1 & 1 & 1 & 1 & 2 & 1 & 2 & 3 \\
\hline Total & & 60 & 60 & 100 & 40 & 140 & 100 & 100 & 200 \\
\hline
\end{tabular}

Source: Authors' calculations based on ELMPS 2018.

ELMPS, Egypt Labor Market Panel Survey.

9 The 2013 poverty map was never formally published but was made available to the ELMPS team through CAPMAS. 
in some governorates. We sampled the poorest villages from all governorates that had them. Likewise, there are no rural areas in Cairo, Alexandria, Port Said, or Suez. Since the ELMPS sample frame excludes the frontier governorates, the refresher sample likewise excludes them. Overall, we planned for a refresher sample of 2,000 households distributed over 200 geographic clusters (primary sampling units or PSUs). Of those, we allocated 60 clusters to urban areas, 100 to poor rural areas, and 40 to non-poor rural areas. Within strata, sampling was carried out according to the principle of probability proportional to size.

Each cluster was designed to sample 10 households. A list of 12 households per cluster was generated in case some households could not be located and 10 were to be collected. There was some nonresponse. Overall, of a planned 2,000 refresher households, 1,953 were sampled. The response rate ranged from a low of $20 \%$ (only 2 of 10 households collected, which happened in 2 clusters), followed by 3 clusters with a rate of $60 \%, 5$ at $70 \%, 14$ at $80 \%, 26$ at $90 \%, 117$ at $100 \%$, and 16 clusters at $110 \%$ along with 17 clusters at 120\%, where the "additional" households were fielded beyond the intended 10 . The response rate (97.7\% overall) was slightly lower in urban (response rate of 94.2\%) than in rural areas (response rate of 99.1\%), but no other nonresponse patterns were discernable.

\section{Calculation of Attrition and Sample Weights}

In this section, we discuss how the attrition modeling and sampling were incorporated into creating weights for the sample, to ensure that the data remained nationally representative. The starting point for weights for 2012 households in the 2018 sample was their household weights in 2012. These weights were adjusted to account for Type I attrition. The weights of split households were derived from their 2012 households but account for Type II attrition as well as whether any other households may have merged (i.e., share adjustment for component households). These weights are the panel weights that should be used in any panel data analysis. These weights were then brought together with the weights for the refresher sample (which were based on the refresher sample design) and then expanded to the national population in 2018. These combined weights are the ones that should be used in any analysis that uses the 2018 wave as a cross-section. This section details all the specifics of these calculations. ${ }^{10}$

\subsection{Weights for panel and split households}

The main idea behind the weights for the panel component of the sample is to generate weights that weight "up" remaining households whose observable characteristics were similar to those households that attrited. From the Type I attrition model, we estimate $\operatorname{Pr}\left(A_{h}\right)$, the probability of Type I attrition (attrition of the entire household) for 2012 household $h$. There may also be splits from that household; refer to a split household as $s$. For such households we calculate:

$$
\begin{aligned}
\operatorname{Pr}\left(A_{h s}\right) & =1-\operatorname{Pr}(h \text { found and } s \text { found }) \\
& =1-\operatorname{Pr}(h \text { found }) \star \operatorname{Pr}(s \text { found } \mid h \text { found })
\end{aligned}
$$

10 Notation is as in Krafft and Assaad (2021a). 
To adjust for attrition among the 2012 households that were found in 2018, we compute a response adjustment factor, $r_{h}$, for original households:

$$
r_{h}=\frac{1}{1-\operatorname{Pr}\left(A_{h}\right)}
$$

and $r_{h s}$ for split households:

$$
r_{h s}=\frac{1}{\left[1-\operatorname{Pr}\left(A_{h s}\right)\right]^{\star} c_{s}}
$$

where $c_{s}$ is the number of component households. Component households are the number of originating households in the population (not the sample) that contribute individuals to the new, split household. For example, when two individuals leave their natal households to get married, they come from two households that existed in 2012; this would be a case of two component households. Essentially, this household has "double" the probability of selection and this must be accounted for in weighting by using a share correction (dividing by component households) (Himelein, 2014). If a split contains only members from a 2012 household or born since 2012, there is only one component household. ${ }^{11}$

The calculation of the 2018 weights for 2012 households accounts for both the household weight in 2012 and attrition. Denote the 2012 weight (whether cross-section or panel) as $w_{2012}$. We therefore calculate 2018 panel weights as $w_{2018}=w_{2012}{ }^{*} r_{h(s)}$. We normalize the weights (dividing by the mean weight) to have a mean of one. When we subsequently normalize the refresher weights, this allows 2012 and refresher households to contribute equally to the sample, on average.

\subsection{Weights for refresher sample}

In addition to the 2012 sample, the 2018 wave included a refresher sample over-sampling the 1,000 poorest villages. This subsection describes the creation of the refresher sample weights. These weights can stand alone, and thus serve as further validation of the full sample, as well as feed into the 2018 combined sample weights. Since our sampling strategy was to sample households in a two-stage stratified cluster sample, weights were initially calculated at the household level.

Each stratum in governorate $g$, urban/rural location $l$, and poor $v s$. non-poor area $s$ is made up of a certain number of clusters $P_{g, l, s}$ as indicated in Table 7. Given that each cluster $p$ in the refresher sample is designed to have 10 households, the total number of households per stratum is given as:

$$
h_{g, l, s}=\sum_{p=1}^{P_{g, l, s}} 10
$$

To incorporate deviations from the planned 10 households per cluster, we accounted for the cluster level nonresponse rate. Households start with weight, $w_{p}$, such that they represent

11 When calculating panel weights rather than wave-specific cross-sectional weights the share correction was omitted. 
the planned number of households per cluster, based on the observed number of households in the cluster, $m_{p}$ :

$$
w_{p}=\frac{10}{m_{p}}
$$

We have population counts from the April 2017 Egyptian Population Census for each of our strata, which we use to weight our sample. Denote the census count of the population in a given stratum as $c_{g, l, s}$. We, therefore, calculate household weights as:

$$
w_{p, g, l, s}=w_{p} \frac{c_{g, l, s}}{h_{g, l, s}}
$$

Using the Population Census to ex-post weight households necessarily generates expansion weights that yield the same number of households as in the population. However, they do not necessarily yield the same number of individuals. We also allow for individual nonresponse (refusal) as part of the individual consent process (71 individuals in the refresher and 490 in the panel refused or could not be completed). Individuals would still be listed in the roster, collected at the household level, but not have the individual interview data. To account for potentially age-group (e) and sex-specific $(x)$ nonresponse, we calculated an age and sex-specific nonresponse rate of $r_{x, e}$ We then adjusted the household weight by this nonresponse to get an individual weight, as:

$$
w_{p, g, l, s, x, e}=\frac{w_{p, g, l, s}}{1-r_{x, e}}
$$

\subsection{Combined sample weights}

To combine the refresher and panel samples into a single panel with a unified set of weights, first we divided the weights in each group (refresher and from 2012) by their means to have a mean of one. The process for the combined weights follows a very similar structure to the latter part of the refresher weight construction. If $\tilde{w}_{g, l}$ is the normalized weight for a household (either refresher or panel) in a particular governorate-urban/rural location combination, we then calculate the household combined sample weight as:

$$
w_{g, l}=\tilde{w}_{g, l} \frac{c_{g, l}}{\sum \tilde{w}_{g, l}}
$$

where $c_{g, l}$ is the number of households in the 2017 Census for that same governorate-urban/ rural location combination. Again, we allow for sex and age-group-specific nonresponse $\left(r_{x, e}\right)$ and adjust to create individual weights as:

$$
w_{g, l, x, e}=\frac{w_{g, l}}{1-r_{x, e}}
$$

\section{Improvements in Retrospective Data Collection}

An important component of the ELMPS and other LMPSs is the labor market history module. It is intended to capture all labor market statuses (lasting 6 months or more) for those who ever 
worked. Research leveraging the multiple panel waves of the ELMPS and comparing the retrospective data from latter rounds to the contemporaneous data in earlier rounds demonstrated that while overall the quality of the labor market history module was good, specific statuses tended to be misreported (Assaad et al., 2018). Nonemployment (being unemployed or out of the labor force) in particular tended to be missed, perhaps because enumerators or respondents did not think of this as a labor market status.

Starting in the JLMPS 2016 survey, we implemented changes in the design of the module. We added questions specifically asking about any period of nonemployment after school exit and before the first job, as well as whether the respondent wanted and was available to work, and whether they searched for work, in this period. We then asked about the first job. At the end of the first (and every subsequent) job question series, we asked whether there was a period of nonemployment following the job and its nature. The goal of these additions was to better detect nonemployment statuses and timing among those who had ever worked. We also added questions to the work detection section for those who had never worked and were not currently unemployed (we already had dates of current unemployment), to ask if they had ever sought work and the dates, to capture initial unemployment that had ended for the never worked; these are primarily women who have high rates of unemployment and tend to leave the labor force if they cannot find a suitable job (Assaad and Krafft, 2016b; Dougherty, 2014; Krafft et al., 2019).

In this section, we use the retrospective data from the ELMPS 2018, with the improvements in retrospective data reporting, to construct a retrospective status in 2012 and compare this with the contemporaneous ELMPS 2012 data, for those who were present in both waves, aged 20-44 years in 2012 (thus in prime working years in both 2012 and 2018). Figure 1 compares the specific statuses in 2012 with the retrospective report about 2012 from the 2018 data, by sex. As was the case when comparing 2012, 2006, and 1998 data (Assaad et al., 2018), certain statuses tended to be reported quite consistently, such as public sector work (79\%). While men tend to report employment consistently as employment, there are differences in formality, regularity, and being self-employed, an employer, or an unpaid family worker. This is likely due to transitions within a status, for example, switching from self-employment to having an employee or vice versa, a very common dynamic (Krafft, 2016). Women tend to underreport employment, aside from public sector employment. Notably, although unemployment is still not very accurate, it is substantially improved in reporting consistency compared to the past design (Assaad et al., 2018). While comparing the 2006 and 2012 data showed a consistent alignment of $13 \%$ for unemployment (Assaad et al., 2018), this had risen to $24 \%$ when comparing 2012 and 2018 with the new design.

As a result of the improvements in the retrospective module, labor market aggregates are, on average, much more consistent across the contemporaneous and retrospective data. Figure 2 shows the distribution of labor market statuses as reported contemporaneously in 2012 and retrospectively from 2018 for 2012 (for those 20-44 years in 2012). The previous data design led to major underreporting of employment, particularly for women, but that is substantially reduced. While contemporaneously in 2006, 28\% of women were employed, only $21 \%$ were employed in the retrospective data from 2012 for 2006 (Assaad et al., 2018). In 2012, $20 \%$ of women were employed contemporaneously, and the 2018 report for 2012 is 17\%, a much smaller gap. Unemployment is also more consistently detected in the aggregate; as a share of 
Figure 1 Labor market status, as reported retrospectively for 2012 from 2018 data, by sex and contemporaneous status for 2012, individuals aged 20-44 years in 2012 and present in both waves (percentage).

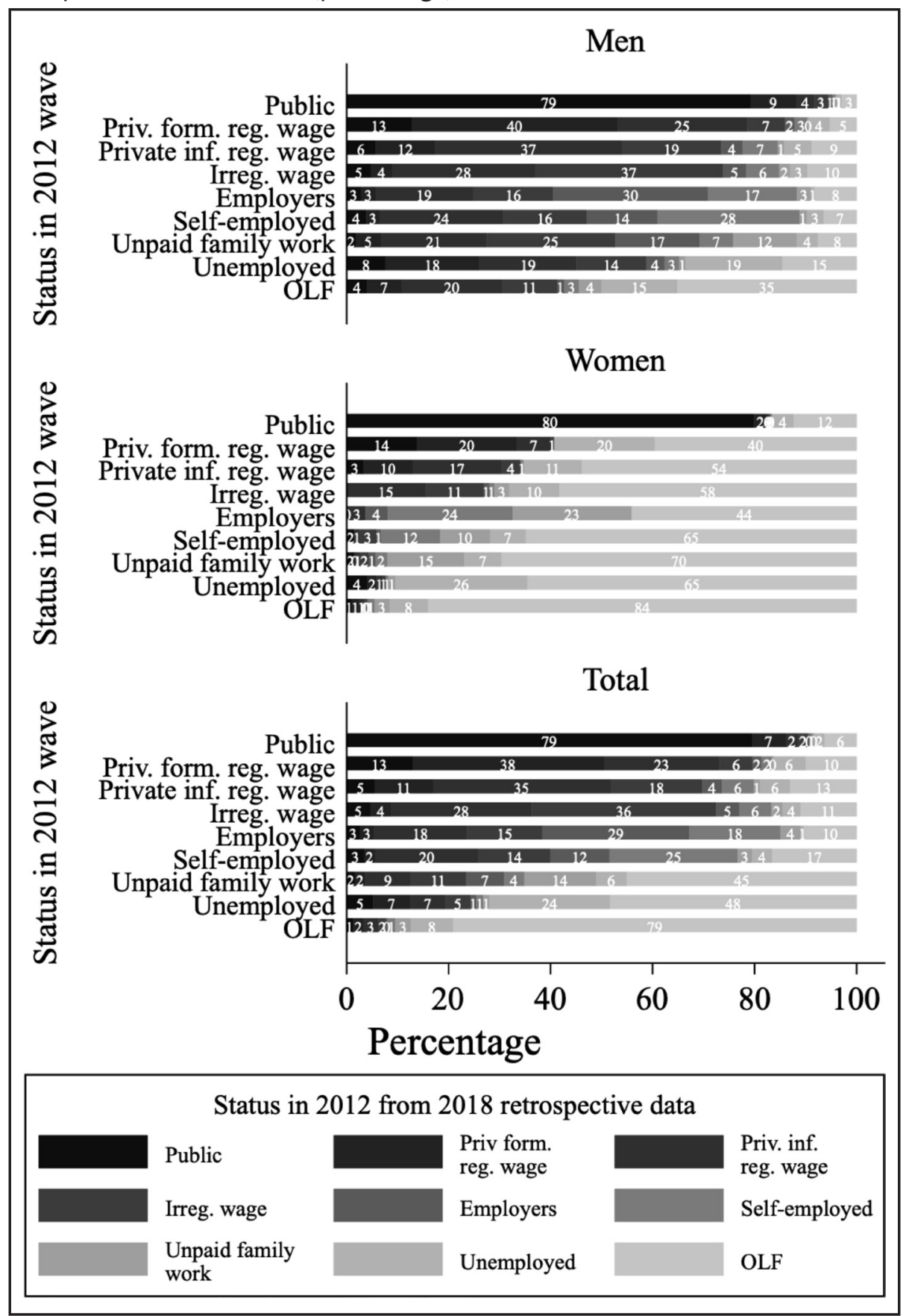

Source: Authors' calculations from ELMPS 2012 and ELMPS 2018 retrospective data. ELMPS, Egypt Labor Market Panel Survey.

the population, it is actually slightly overestimated, at $7 \%$ retrospectively and $6 \%$ contemporaneously, with a similar one percentage point overestimation for both men and women. This overestimation is likely due to periods of nonemployment that include some unemployment and some out of the labor force being detected primarily as unemployment. The results showing consistent aggregates suggest that the inconsistencies in the exact status shown in Figure 1 are likely due, in part, to timing. This point was raised even with the prior data design, whereby, although only $13 \%$ of unemployment spells in 2006 contemporaneously were aligned in the 
Figure 2 Labor market status, as reported contemporaneously for 2012 and as reported retrospectively for 2012 from 2018 data, by sex, individuals aged 20-44 years in 2012 and present in both waves (percentage).

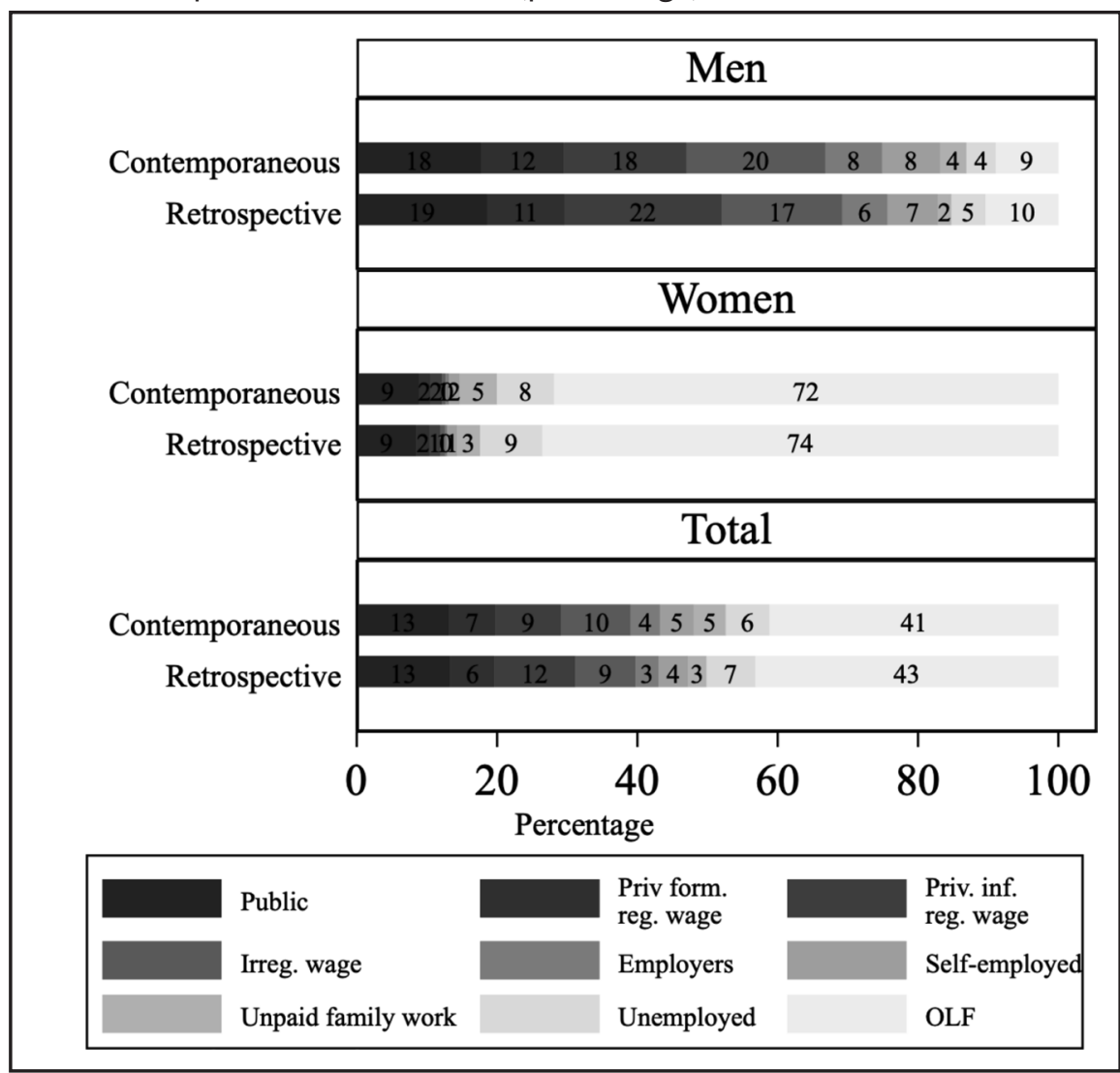

Source: Authors' calculations from ELMPS 2012 and ELMPS 2018 retrospective data. ELMPS, Egypt Labor Market Panel Survey.

2012 retrospective data for 2006, a further $17 \%$ existed but were off timing-wise by $1-5$ years (Assaad et al., 2018).

\section{Comparisons with Other Data Sources for Egypt}

In this section, we compare several demographic and labor market indicators from the ELMPS waves with other data sources and evaluate the representativeness of the ELMPS data. We use the LFS rounds from 2001 to 2018 and the Egypt Population Census $2017^{12}$ as comparators. In examining age distributions, we also use Egypt's 2006 Population Census to examine the changes over time (Minnesota Population Center, 2018). We obtained the key labor market statistics of LFS 2001-2007 from the International Labor Organization's ILOSTAT (ILO, 2019) and analyzed the microdata for 2008-2017. ${ }^{13,14}$ We used ILOSTAT for the years 2001-2007 for two reasons: first because calculations from the microdata were inconsistent with the published figures, and second because this time period covered ages 15-64 years, the focus of our microdata analysis, but subsequently were 15+. Key labor market indicators were missing for

12 Based on the published Census report (CAPMAS, 2017).

13 Harmonized LFSs are available from ERF's OAMDI (OAMDI, 2019c).

14 Employment rates were missing from the ILOSTAT. We, however, were able to calculate the employment rate $(e)$ from the labor force participation rate $(l)$ and unemployment rate $(u)$ using the following formula: $e=l(1-u)$. 
years 2003 and 2004 and unemployment and thus employment were missing in 2005. In addition, we discuss the published LFS numbers from the four quarters of 2018 and the first two quarters of 2019 (CAPMAS, 2019a, b), since the microdata were not yet publicly available. ${ }^{15}$

The different surveys have slightly different universes. While the ELMPS covered all of Egypt except the Frontier governorates, the Census and LFS include the Frontier governorates as well. The Frontier governorates include Red Sea, El-Wadi El-Gedid, Matrouh, and North and South Sinai. Since these governorates had 1.7\% of Egypt's population in the 2017 Census, we do not expect this to substantially alter the comparability (CAPMAS, 2019c).

We first undertake comparisons in terms of demographic characteristics, such as age, household size, marital status, and education. When we focus on the demographic outcomes, we specifically compare ELMPS 2018 with LFS 2014, LFS 2017, and Census $2017 .{ }^{16}$ We include two rounds of the LFS because, as we will show below, we observed a substantial difference in demographic outcomes starting in LFS 2015 that continued through LFS 2017.

We make use of the LFS to assess and compare labor market outcomes, specifically employment, unemployment, and labor force participation (LFP) rates. ${ }^{17} \mathrm{We}$ analyze these outcomes by sex for ages 15-64. We follow the definition of employment as "work for pay or profit" as specified in the 19th International Conference of Labor Statisticians (ILO, 2013) to calculate these statistics. This is also referred to as the market definition of employment. Against this definition, if someone worked for at least $1 \mathrm{~h}$ in the past week as either a wage worker, employer, self-employed worker, or unpaid family worker, producing goods for market exchange, then that individual was considered to be employed. On the other hand, if someone was willing to work, had actively searched for work in the preceding 3 months, was available to start working in the following 2 weeks but did not even work for an hour over the past 1 week, then that person was considered to be unemployed. A person was considered to be in the labor force if she or he was employed or unemployed.

We also present the $95 \%$ confidence intervals (CIs) of each labor market indicator calculated from the ELMPS. The CIs take into account the contemporaneous cluster and strata of the ELMPS. Comparing the CIs with other statistics allows us to assess the degree to which any differences in results are likely to be purely due to sampling variability. In addition, we also separately add the same statistics for the ELMPS 2018 refresher sample. Since the ELMPS 2018 refresher is an independent sample, covering the same time frame and using the same questionnaire, fielding practices, and enumerators, this is a particularly valuable test of whether any differences in results are due to the panel sample (and potentially attrition).

\subsection{Demographic comparisons}

In this section, we compare the demographics of ELMPS 2018 with other sources. We start with the size of the population, and then discuss its household size, age structure, marital status, and educational attainment. The 2017 Population Census enumerated 23.1 million

15 The labor force participation rate and employment rate for the year 2018 are for $15+$ population. While the numerator of the unemployment rate is the total size of unemployed population between ages 15 and 64, the denominator is the size of labor force for $15+$ population. We, therefore, do not include these statistics in our graphs.

16 For additional comparisons of previous waves of the ELMPS, see Assaad and Krafft (2013).

17 We do not compare labor market outcomes with the Census, since previous research has demonstrated that labor market outcomes are poorly measured in the Census (Assaad, 1997). 
households (within the governorates covered by ELMPS), which contained 93.2 million individuals (48.1 million men and 45.1 million women). Given the design of the weights, both the overall ELMPS and the refresher sample generate the same number of households. From the whole ELMPS sample, when we calculated the expansion-weighted population numbers, after adjusting for individual nonresponse, we found 88.6 million individuals (44.0 million men and 44.6 million women). When we calculated the refresher sample expansion-weighted population numbers, after adjusting for individual nonresponse, we found 91.4 million individuals (45.7 million men and 45.8 million women). Both the refresher sample and the full sample found fewer individuals, and especially fewer men, than the Census.

One of the reasons for different numbers of individuals across data sources may be different definitions of households implemented in the different data sources, an issue observed in ELMPS 2012 as well (Assaad and Krafft, 2013). As Figure 3 shows, ELMPS 2018 sampled more households of one person (11\%) than the Census (5\%), with the LFSs between the two (8\%). Likewise, while the ELMPS found $16 \%$ of households had one individual, the Census found $8 \%$ of households did so, and the LFSs $13-14 \%$. Correspondingly, the Census found that 23\% of households had three people, while the ELMPS found 16\% and LFSs 13-14\%. Likewise, the Census found that more households (27\%) were four persons than the ELMPS (20\%) or LFSs (21-23\%). The sampling of households with five members or above in ELMPS 2018 was almost identical to that of the Census.

Egypt's population is young and has a well-known "youth bulge," whereby a decline in mortality in the early 1980s followed by a delayed decline in fertility led to a particularly large youth population (Assaad and Roudi-Fahimi, 2007; Krafft and Assaad, 2014; Robinson and El-Zanaty, 2006). The youth bulge were young adults by 2018 (Krafft et al., 2019). Figure 4

Figure 3 Comparison of household size (percentage of households), by data source.

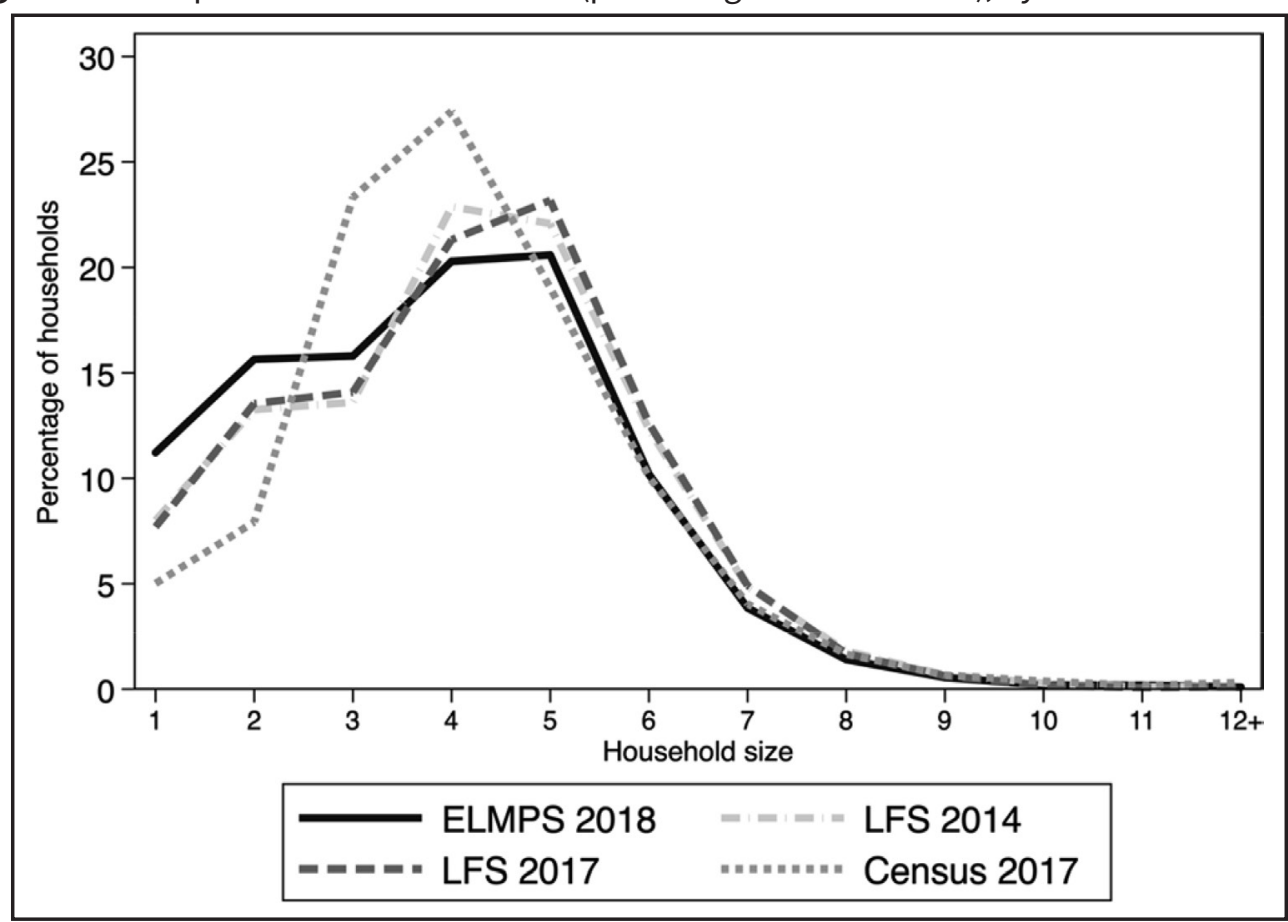

Source: Authors' calculations from LFS 2014 and 2017, ELMPS 2018, and Egypt Population Census 2017 Table 1-9 (CAPMAS, 2017). CAPMAS, Central Agency for Public Mobilization and Statistics; ELMPS, Egypt Labor Market Panel Survey; LFS, Labor Force Survey. 
Figure 4 Comparison of age distribution (percentage in 5-year age group), by data source.

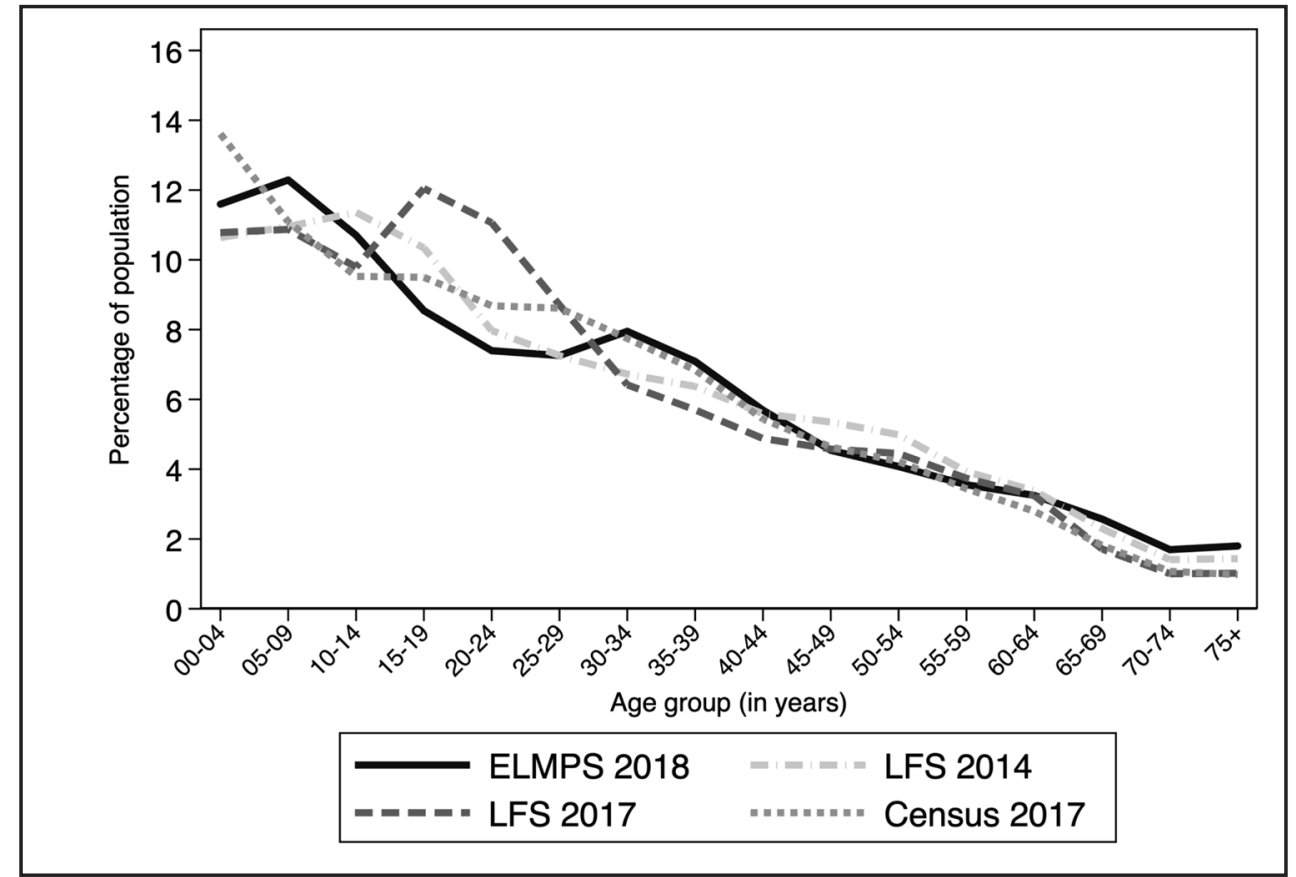

Source: Authors' calculations from LFS 2014, 2017, ELMPS 2018, and Egypt Census 2017 Table 1-2 (CAPMAS, 2017). CAPMAS, Central Agency for Public Mobilization and Statistics; ELMPS, Egypt Labor Market Panel Survey; LFS, Labor Force Survey.

presents the distribution of the population by 5-year age groups for the ELMPS 2018, Census 2017, and LFS 2014 and 2017 rounds. While for ages starting around 40, the data had similar age distributions, at younger ages they diverged substantially. The ELMPS 2018 and Census 2017 had a similar share of 30-39-year-olds, but the LFS 2014 and 2017 had slightly fewer. The LFS 2017 was strikingly different than other sources at ages 15-24, showing a large youth bulge at those ages, which was not reflected in the LFS 2014. The LFS 2014 was somewhat more similar to the ELMPS 2018, with some more 20-24-year-olds and somewhat fewer children under 10. The 2017 Census showed less of a "trough" at ages 20-24 than the ELMPS, slightly fewer children 5-9, and more $0-4$. These different age compositions are important to keep in mind when considering labor statistics that are strongly related to age, for instance, unemployment rates.

Figure 5 compares the age distribution of the sources in Figure 4 with the 2006 Population Census. To compare the LFS and ELMPS, we calculate what individuals' ages would have been in 2006 and exclude those who were born after 2006. Because we only have reports, not microdata, for the Census 2017, we subtract two age groups (10 years, so off by 1 year). The spike in ages 15-24 observed above in the LFS is prominent as a spike in ages 5-9 in 2006, and while larger for the 2017 wave, it was also visible in the 2014 wave. The 2006 and 2017 censuses also diverged in terms of the share of the population at younger ages, with the 2017 Census having a higher share from ages 0 to 14 in 2006, but not thereafter. Both the Censuses and the ELMPS show a very similar youth population, starting at 15-19 years in 2006. The Census 2006 shows it as a youth bulge, with less youth thereafter, whereas the higher share of 0-14 years means the bulge is less pronounced in Census 2017. Overall, the ELMPS 2018 is very consistent with the 2006 Census, and the 2017 Census for ages 15+ (in 2006), but diverged at younger ages.

Figure 6 presents the distribution of the population aged $\geq 18$ years by marital status. ELMPS 2018 and Census 2017 align in terms of the share of the population married (68-69\%). 
Figure 5 Comparison of age distribution, age in 2006 (percentage in 5-year age group), by data source.

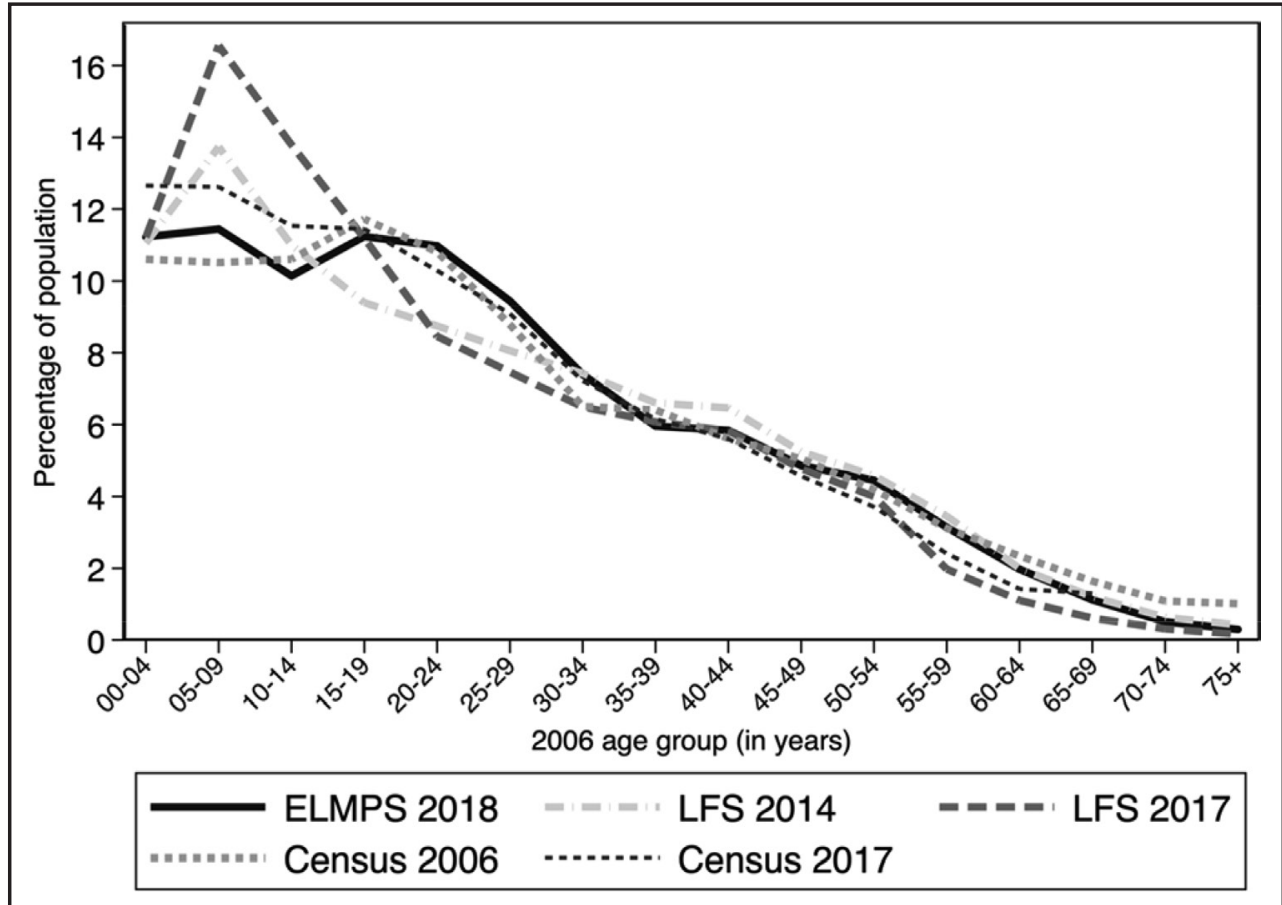

Source: Authors' calculations from LFS 2014, 2017, ELMPS 2018, and Egypt Census 2017 Table 1-2 (CAPMAS, 2017). CAPMAS, Central Agency for Public Mobilization and Statistics; ELMPS, Egypt Labor Market Panel Survey; LFS, Labor Force Survey.

Figure 6 Marital status (percentage of individuals aged $\geq 18$ years), by data source.

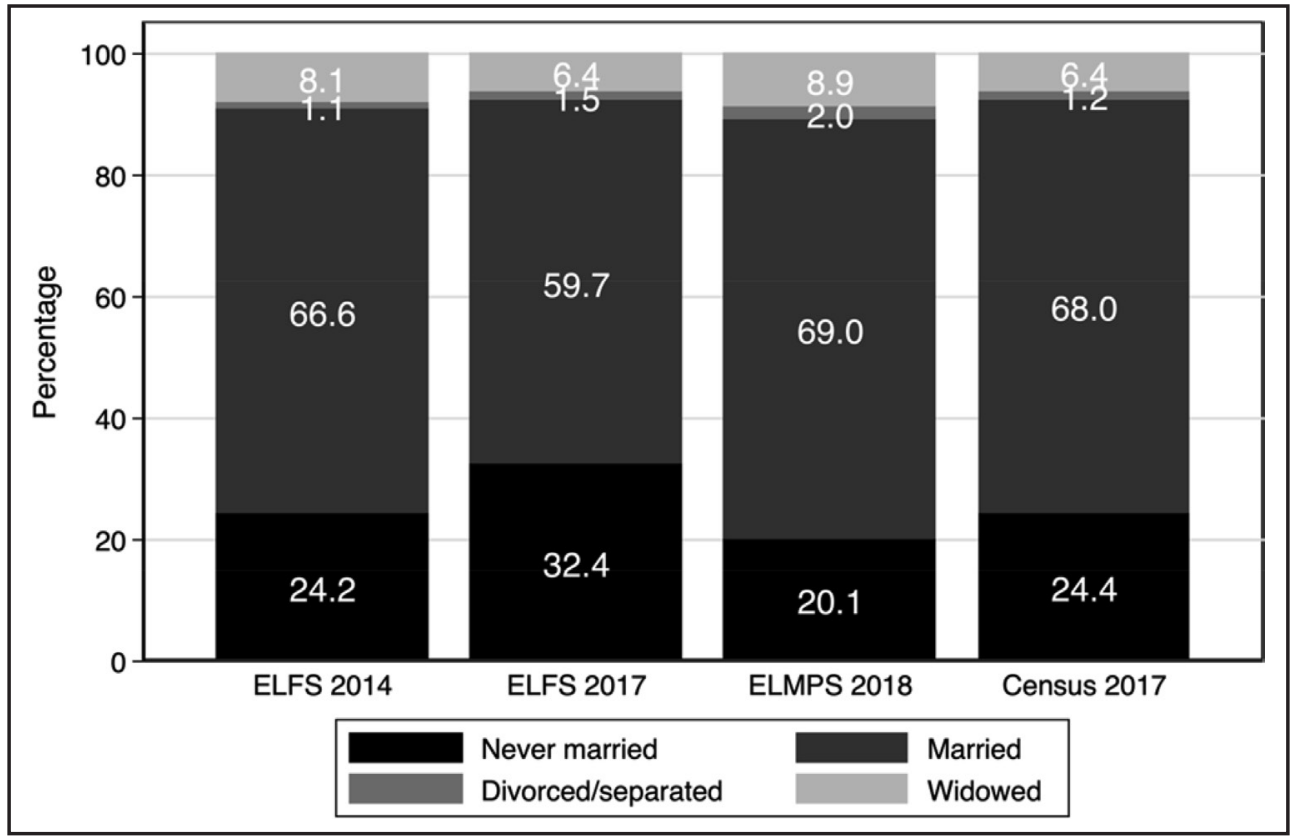

Source: Authors' calculations from LFS 2014 and 2017, ELMPS 2018, and Egypt Census 2017 Table 1-10 (CAPMAS, 2017). CAPMAS, Central Agency for Public Mobilization and Statistics; ELMPS, Egypt Labor Market Panel Survey; LFS, Labor Force Survey.

ELMPS found more divorced (2.0\%) individuals than the Census (1.2\%) and more widowed (8.9\% ELMPS vs. 6.4\% Census). These variations are similar to those across LFSs. As a result, ELMPS 2018 found fewer never-married individuals (20.1\%) than the Census 2017 (24.4\%), 
Figure 7 Educational attainment (percentage of individuals aged $\geq 10$ years), by data source.

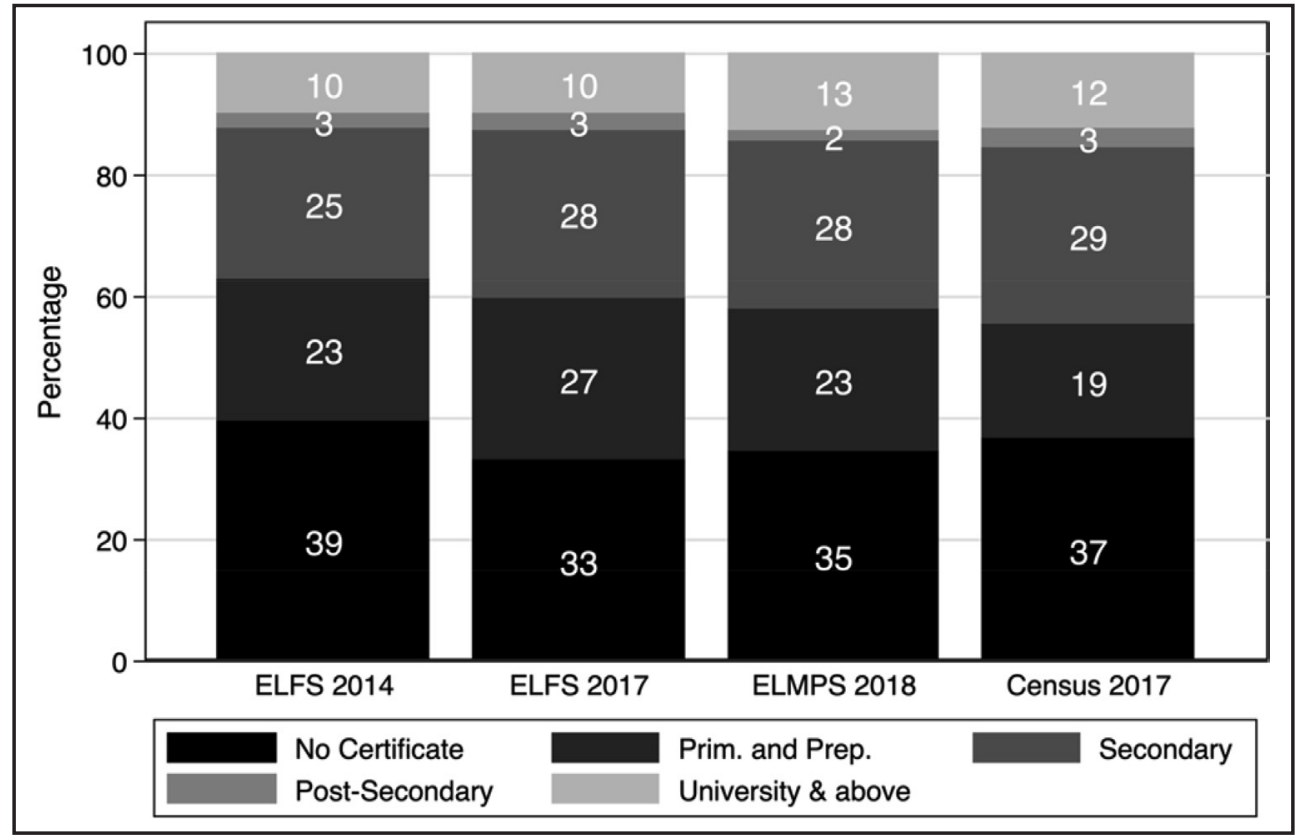

Source: Authors' calculations from LFS 2014 and 2017, ELMPS 2018, and Egypt Census 2017 Table 1-3 (CAPMAS, 2017). CAPMAS, Central Agency for Public Mobilization and Statistics; ELMPS, Egypt Labor Market Panel Survey; LFS, Labor Force Survey.

LFS 2014 (24.2\%), or LFS 2017 (32.4\%). These differences may, however, be due to differences in the age composition of each data source, as, for instance, LFS had far more 15-24-year-olds. Differences may also be due to difficulties in distinguishing between different categories of unmarried individuals in large-scale data collection exercises that do not collect the information from the individual person, such as the census and the LFSs.

Figure 7 presents the distribution of the population aged $\geq 10$ years by educational attainment and data source. Patterns are generally similar. For instance, ELMPS 2018 sampled individuals with no certificate (35\%) slightly less than the Census (37\%). ELMPS found a similar share of university graduates (13\%) as the Census (12\%) and more than the LFSs (10\%), although this may be driven by age composition differences. The share in secondary was similar across ELMPS 2018, Census 2017, and LFS 2017 (28-29\%), although LFS 2014 was lower (25\%). Differences were largest in terms of primary and preparatory education, 19\% in the Census, 23\% in ELMPS 2018 and LFS 2014, and 27\% in LFS 2017.

\subsection{Labor market outcome comparisons}

In this section, we turn to comparisons of labor market outcomes between the ELMPS and LFS. We first look at trends over time and comparisons across data sources. We then, given some differences in labor market aggregates as well as demographics, show labor market outcomes by age and sex, to disentangle composition differences from differences in outcomes after accounting for composition. ${ }^{18}$

18 Krafft et al., (2019) explore patterns of labor supply in detail using the ELMPS. 
Figure 8 Labor force participation rate (percentage), by sex and data source, ages 15-64, 1998-2018.

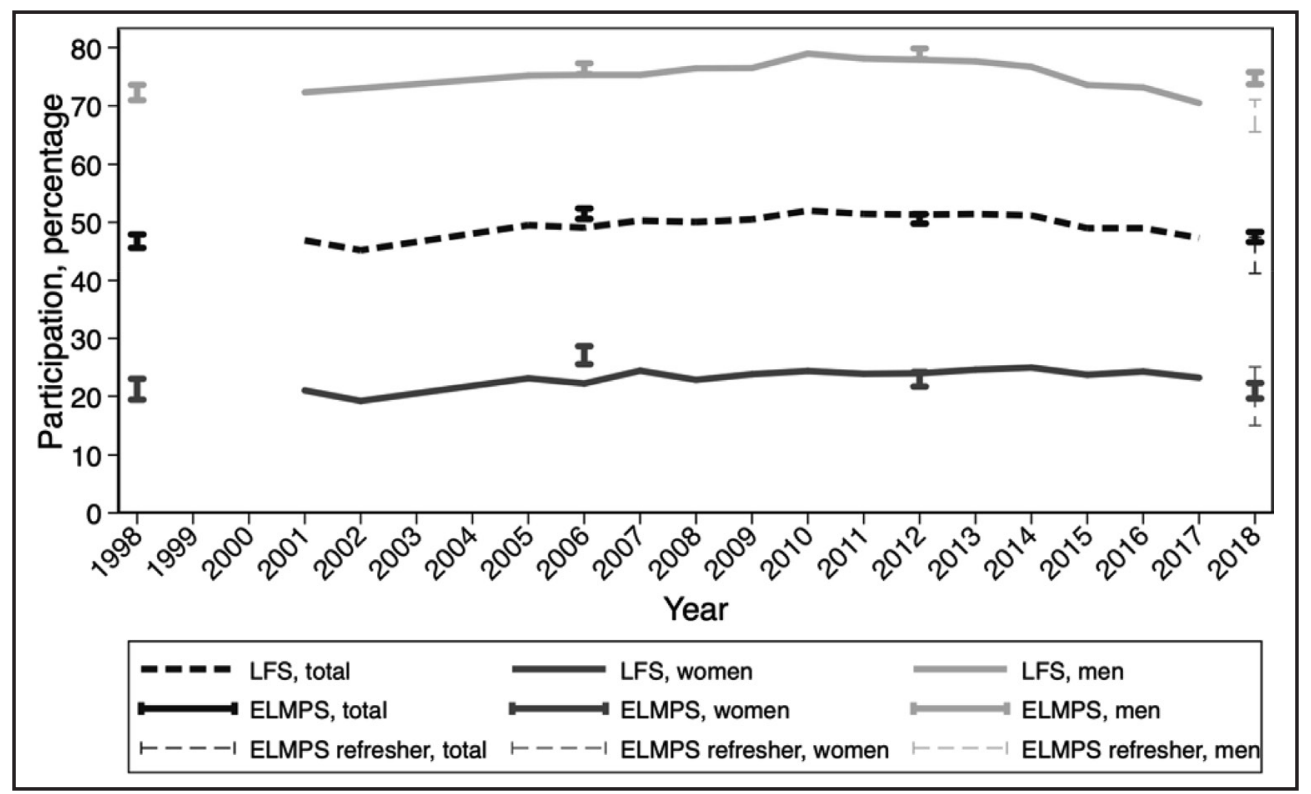

Source: Authors' calculations from LFS 2008-2017, ELMPS 1998-2018. LFS 2001-2007 from ILOSTAT (ILO, 2019). ELMPS, Egypt Labor Market Panel Survey; ILO, International Labor Organization; LFS, Labor Force Survey.

\subsubsection{Labor force participation (LFP)}

Figure 8 presents the LFP rate of the population aged 15-64 years by sex and in total. The figure includes LFS 2001-2017 rates and the rates and CIs from ELMPS 1998, 2006, 2012, and 2018. While the total LFP rose from 1998 to 2006, it plateaued in the late 2000s and began falling thereafter. The drop in LFP has been particularly pronounced in the LFS in recent years, dropping from 49\% in 2016 to 47\% in 2017. The ELMPS 2018 found a similar LFP (47\%) as the 2017 LFS. Since the LFS published statistics are for 15+ they are not directly comparable; however, comparing the 2018 and first two quarter of 2019 numbers with those of the 2017 LFS shows a continuing decline in LFP rates among ages 15+ (CAPMAS, 2019a, b). Examining the results by sex, the ELMPS female LFP rate is slightly below and the male rate slightly above the trend from the LFS. The ELMPS has historically found higher participation rates than the LFS, which may be in part due to the focus on an individual responding himself or herself, rather than using a proxy respondent (Assaad and Krafft, 2013). The CIs from the refresher sample for women and for the overall rate, but not for men, overlap with the full ELMPS point estimates, suggesting that there may be some small differences in the representativeness of the sample.

Figure 9 presents the LFP rate by age, sex, and data source. Generally, the pattern for men is similar across sources. For men, LFS 2017 had a slightly lower participation rate for ages 15-20 and a slightly higher participation rate for ages 25-45 than ELMPS 2018. In the LFS 2014, participation was higher for all ages. The pattern across time, from 2014 to 2017 and 2018 shows a clear decline in participation across ages. For men, differences in the overall rates were likely driven by differences in age composition, given how similar patterns are by age. For women, participation from LFS 2017 was higher than ELMPS 2018 for ages 15-35, while the ELMPS participation rate was higher than the LFS, but only slightly so, for ages 35-60. We return to these differences for women below, in examining their types of employment. 


\subsubsection{Employment rates}

Figure 10 presents employment rates by data source. Employment rates follow a similar pattern to LFP rates in rising through approximately 2010 and then declining thereafter (the declining trend continued into 2018/19 (CAPMAS, 2019a, b)). The decline, particularly among men, is a notable new trend, although it must be interpreted with some caution given the composition patterns by age in the LFS. The results with the ELMPS 2018 compared with LFS again show similar women's employment, slightly higher total employment, and higher men's employment. The refresher CIs overlap the full sample point estimates in 2018 for the total and for women's

Figure 9 Labor force participation rates (percentage) by sex, age, and data source.

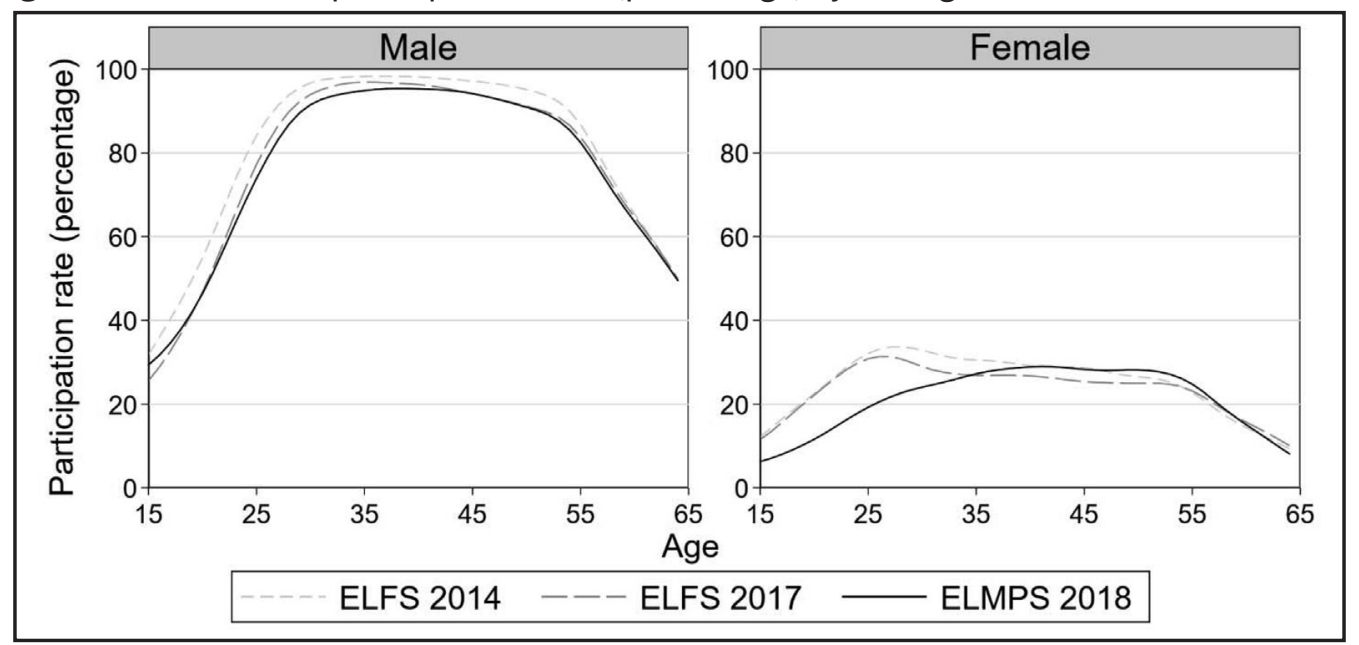

Source: Authors' calculations from LFS 2014, 2017, and ELMPS 2018.

Notes: Running mean smoother, bandwidth 0.4. ELMPS, Egypt Labor Market Panel Survey; LFP, labor force participation; LFS, Labor Force Survey.

Figure 10 Employment rates (percentage) by sex and data source, ages 15-64, 1998-2018.

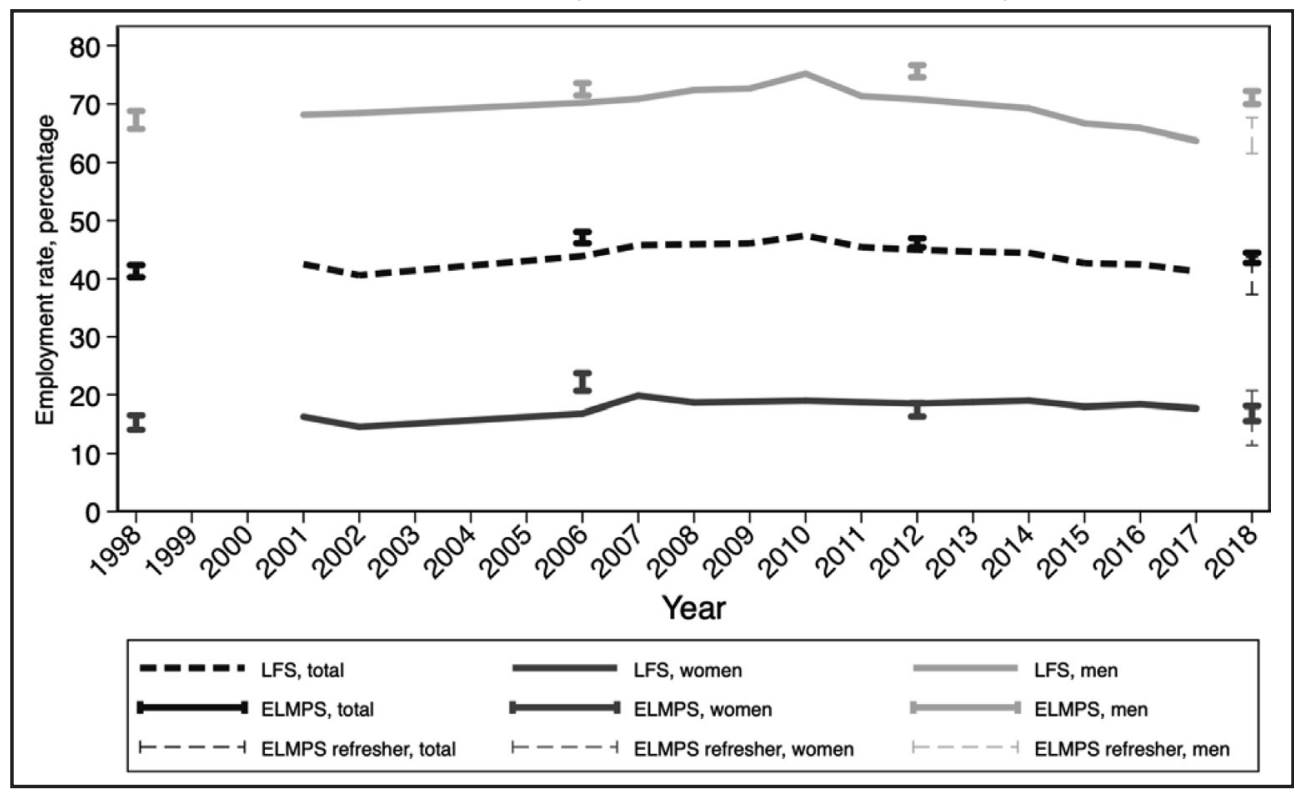

Source: Authors' calculations from LFS 2008-2017, ELMPS 1998-2018. LFS 2001-2007 from ILOSTAT (ILO, 2019). ELMPS, Egypt Labor Market Panel Survey; ILO, International Labor Organization; LFS, Labor Force Survey. 
Figure 11 Employment rates (percentage) by sex, age, and data source.

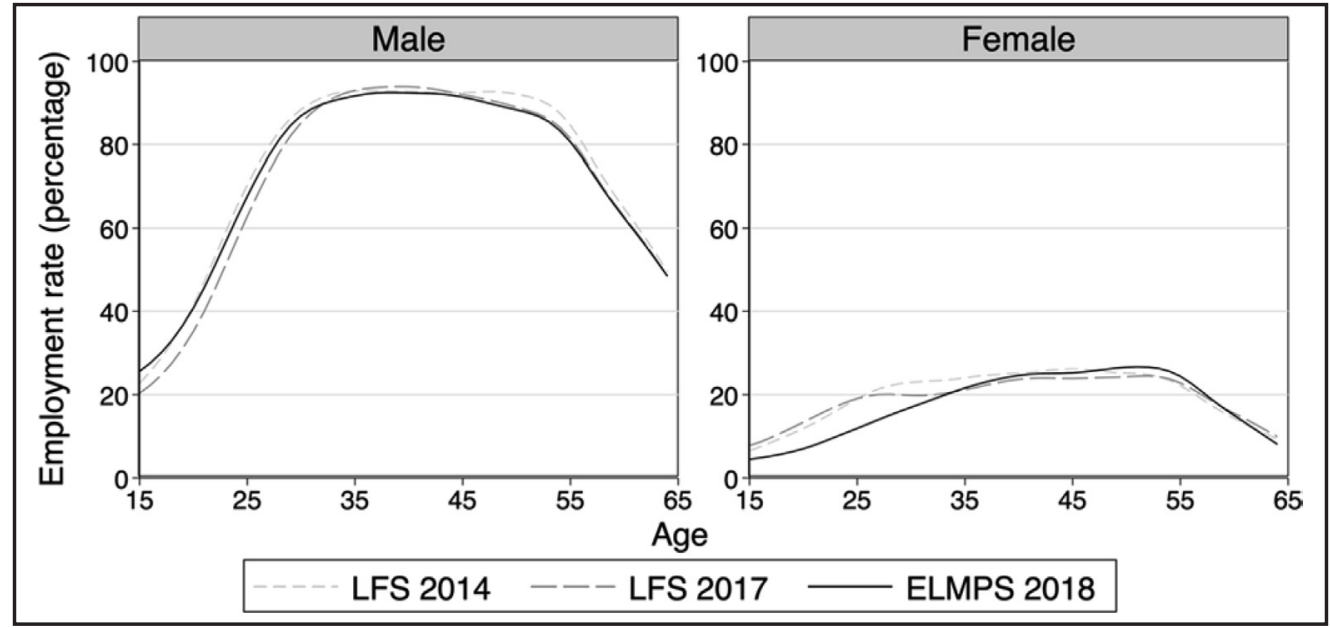

Source: Authors' calculations from LFS 2014, 2017, and ELMPS 2018.

Notes: Running mean smoother, bandwidth 0.4. ELMPS, Egypt Labor Market Panel Survey; LFS, Labor Force Survey.

employment rates, but not for that of men, as in the case of LFP. For men's employment and total employment ELMPS 2006 and 2012 were also higher than LFS.

In Figure 11, we see that employment rates for men, by age, were very similar in the ELMPS 2018 and LFS 2014 and 2017. The drop in prime-age male employment observed in ELMPS 2018 (Krafft et al., 2019) is thus confirmed by other sources. There were only slight differences with the LFS 2017 having lower youth employment rates for men, and the LFS 2014 having higher employment rates for older men. For women, while the employment rates at ages 35 and older were generally similar, with ELMPS 2018 finding slightly more employment at these ages than LFS 2017, there was again a difference at younger ages in employment rates, with ELMPS 2018 estimating lower employment rates for young women, a point we revisit in examining the nature of employment, below.

\subsubsection{Types of employment}

Examining the structure of employment by sex, industry, and data source illustrates important patterns that may explain differences in the overall labor market indicators. Figure 12 examines the structure of employment by industry, specifically comparing agriculture $v s$. nonagriculture and employment status (wage $v s$. non-wage). All data sources agree that the share of workers in agricultural non-wage work has declined over time. However, when the ELMPS data are overlapped with the time trends for the LFS, they show different employment statuses and industries, especially for women in recent years. In particular, recent LFSs have classified far more women as agricultural wage workers and fewer as agricultural non-wage workers. In general, fewer individuals were classified as agricultural non-wage workers, especially among women. It may be that the LFS employment detection questions are picking up more subsistence work as market work. ${ }^{19}$ This phenomenon may explain why more young women were classified as employed in the LFS than ELMPS.

19 Difficulty in capturing the correct employment status of women engaged in agriculture and livestock production has plagued Egyptian data collection efforts for some time. See Anker and Anker (1995); Assaad (1997); Langsten and Salem (2008). 
Figure 12 Structure of employment in terms of industry (agriculture vs. non agriculture) and employment status (wage vs. non-wage), by sex and data source, employed, ages 15-64, 2006-2018.

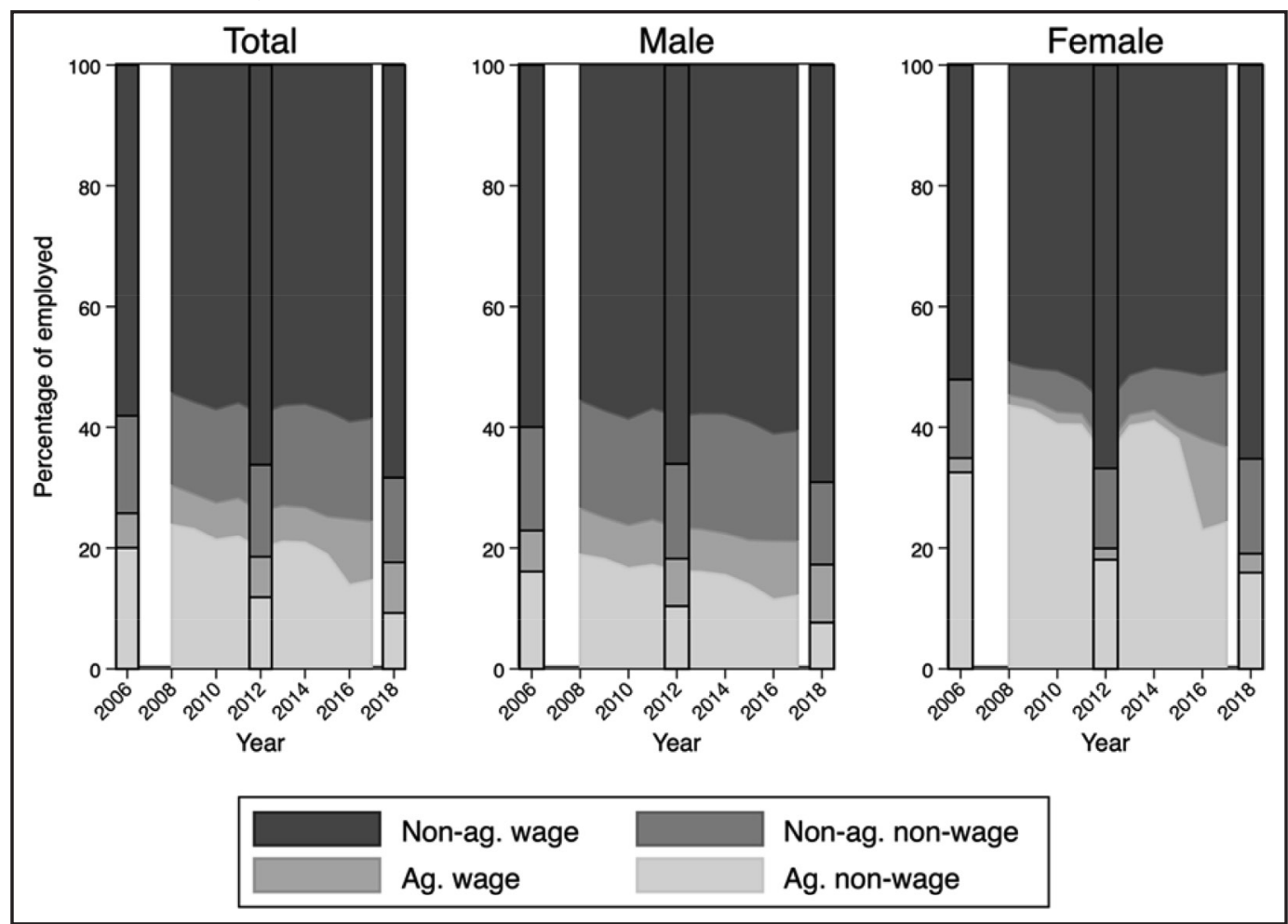

Source: Authors' calculations from LFS 2008-2017 and ELMPS 2006, 2012, and 2018.

Notes: Bars at 2006, 2012, and 2018 from ELMPS. ELMPS, Egypt Labor Market Panel Survey; LFS, Labor Force Survey.

Figure 13 shows the structure of employment for those employed outside of agriculture, by sex, comparing data sources. Slightly fewer years of the LFS are included (2008 is excluded), due to different industry coding systems being used over time. Within non-agricultural activities, the LFS and ELMPS show similar distributions of employment by industry. The results were most similar overall and for men, but differences among women may be due to the relatively low employment rates of women and thus more sampling variability. Women were most likely to be employed in education, followed by the "other" sector, which includes several services. The vast majority of women were employed within these two sectors. Men were distributed across a wider variety of sectors, with a rising share in construction particularly.

\subsubsection{Unemployment rates}

Figure 14 presents the unemployment rates by sex and data source. It is important to keep in mind here that differences in age composition as well as employment and unemployment can contribute to differences in unemployment rates. Unemployment fell from 1998 to the 2000s, and further in the 2006-2008 period, before rising in 2009 and thereafter with the start of the global financial crisis and Egypt's 2011 uprising. Since peaking in 2015, unemployment rates have been declining in the LFS. ELMPS 2018 shows consistently lower unemployment rates than LFS 2017. These rates were, however, consistent with declines in the 2018 LFS and in the first two quarters of 2019, which found that overall unemployment dropped from $10.6 \%$ in Q1 
Figure 13 Structure of employment by industry, sex, and data source, employed, not in agriculture, ages 15-64, 2006-2018.
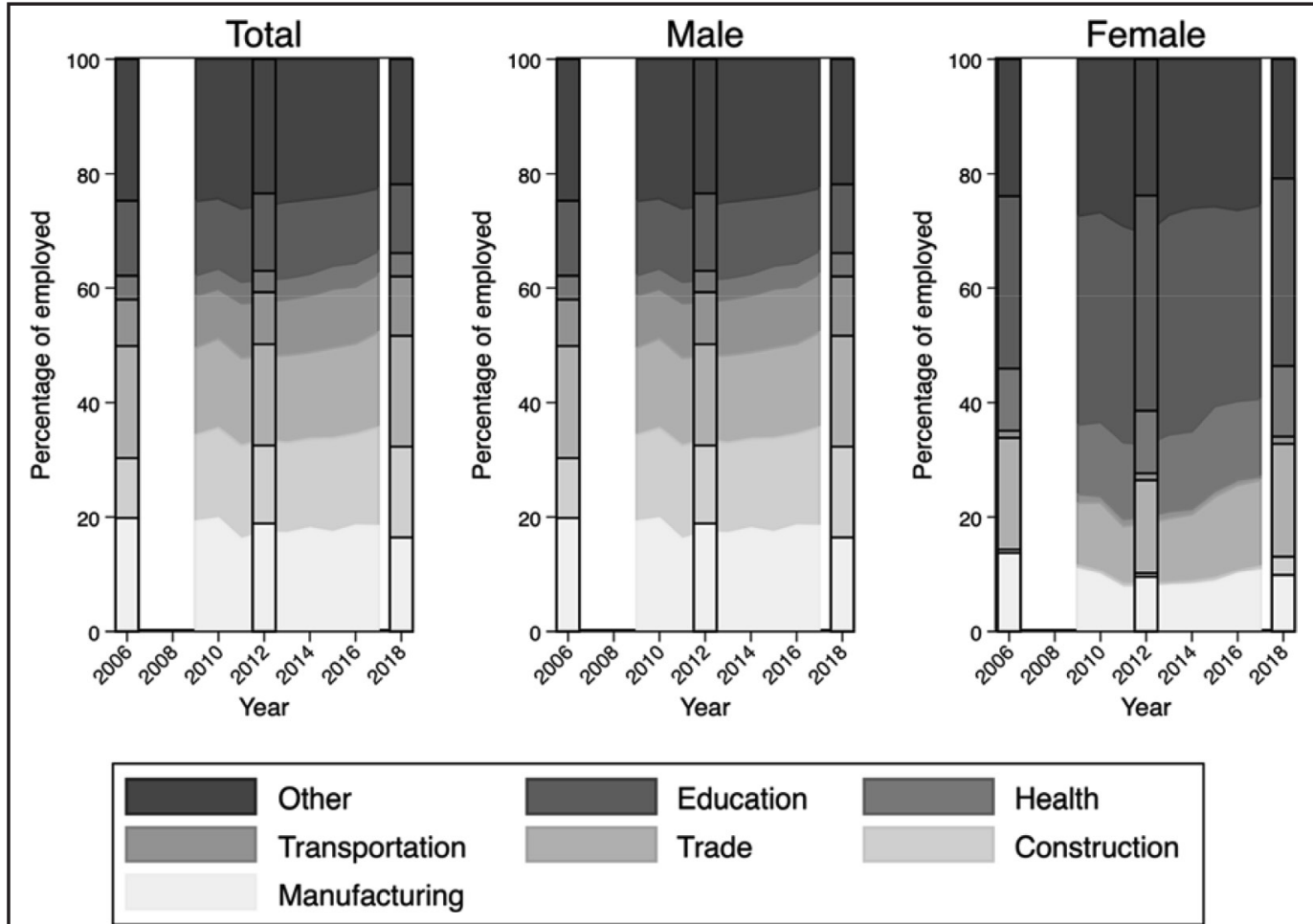

Source: Authors' calculations from LFS 2009-2017 and ELMPS 2006, 2012, and 2018. Note: Trade is "Wholesale and retail trade." Bars at 2006, 2012, and 2018 from ELMPS. ELMPS, Egypt Labor Market Panel Survey; LFS, Labor Force Survey.

Figure 14 Unemployment rates (percentage) by sex and data source, ages 15-64, 1998-2018.

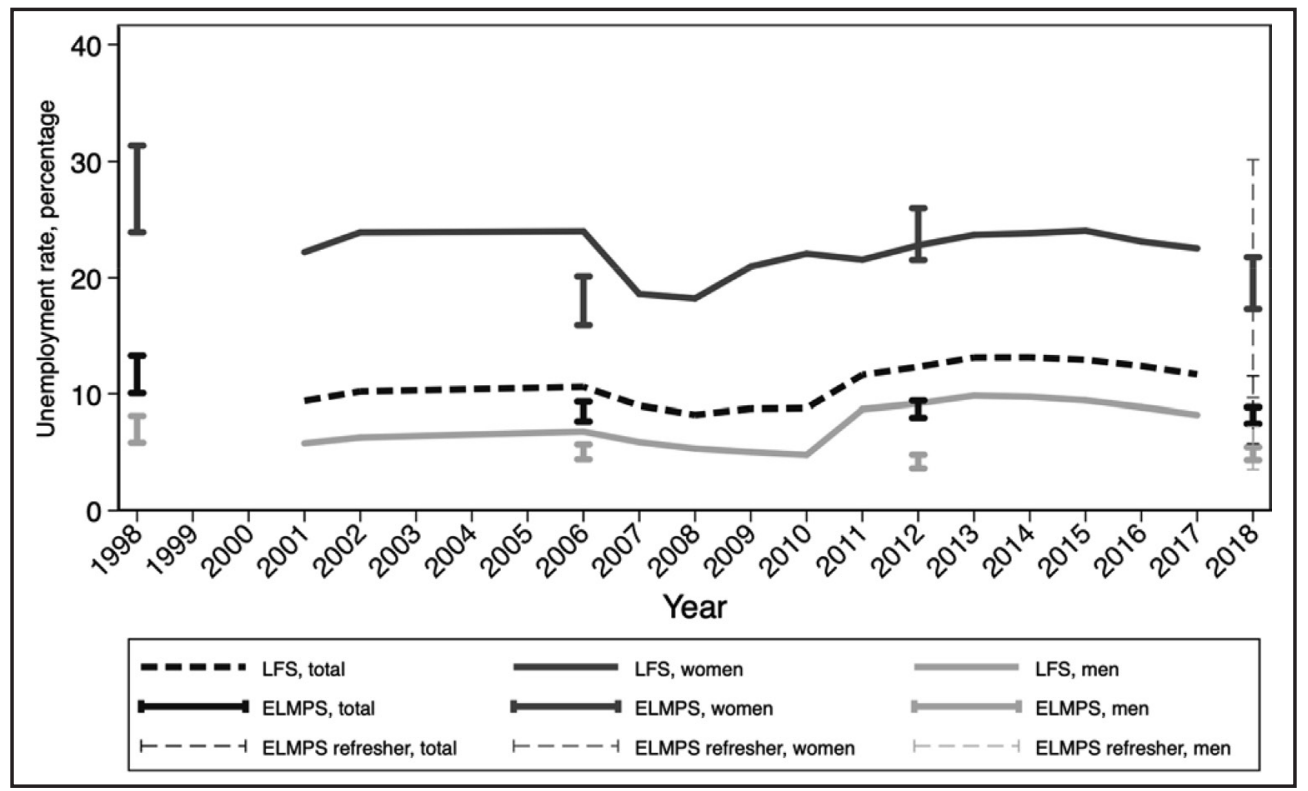

Source: Authors' calculations from LFS 2008-2017, ELMPS 1998-2018. LFS 2001-2007 from ILOSTAT (ILO, 2019). ELMPS, Egypt Labor Market Panel Survey; ILO, International Labor Organization; LFS, Labor Force Survey. 
Figure 15 Unemployment rate (percentage) by sex, age, and data source.

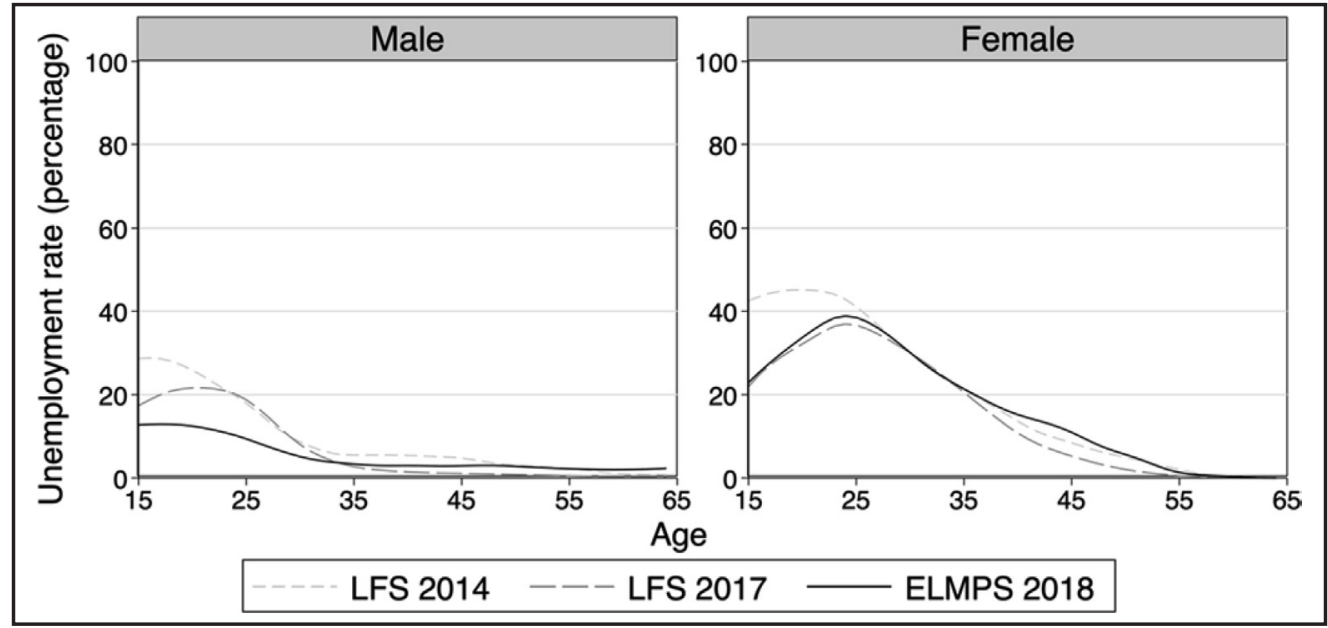

Source: Authors' calculations from LFS 2014, 2017, and ELMPS 2018.

Notes: Running mean smoother, bandwidth 0.5. ELMPS, Egypt Labor Market Panel Survey; LFS, Labor Force Survey.

of 2018 to $9.9 \%$ in Q2, 10.0\% in Q3, 8.9\% in Q4, 8.1\% in Q1 of 2019, and 7.5\% in Q2 of 2019. The ELMPS 2018 estimate of $8.2 \%$ unemployment overall (8.7\% in the refresher sample) is in line with this trend. It is, however, important to keep in mind that discouraged unemployment where individuals were ready and want to work but were not searching - rose between 2012 and 2018 (Krafft et al., 2019). Women have consistently had higher unemployment rates than men and have experienced smaller declines in unemployment over time; they also had more growth in discouraged unemployment (Krafft et al., 2019).

Figure 15 examines the unemployment rate by age. Historically, unemployment in Egypt has been an educated new entrant phenomenon (Krafft and Assaad, 2015; Krafft et al., 2019), and that generally continues to be the case. Here, ELMPS 2018 and LFS 2017 show similar patterns of women's unemployment, with only small differences at older ages, while LFS 2014 shows a higher rate of young women's unemployment from 15 to 24 . The ELMPS and LFSs both show a rise in younger (aged 15-19) men's unemployment, suggesting some shift among men of unemployment toward the younger and less educated (Krafft et al., 2019). LFS 2014 clearly shows higher unemployment among the youngest for both men and women.

\section{Conclusions}

Research and policy depend on high-quality, publicly available data. Particularly in the Middle East and North Africa (MENA) region, including Egypt, there are substantial economic and social challenges that can be informed by high-quality data. Past LMPS waves and especially the previous three waves of the ELMPS have played a key role in research and policy on the labor market and human development issues in Egypt and the broader MENA region. We are confident that the 2018 wave of the ELMPS will contribute likewise. Having two decades worth of panel data is particularly valuable, unique in the region, and rare even globally. The breadth of inter-linked topics, spanning from employment to fertility and gender role attitudes, has proved a rich source for cutting-edge research. Refresher samples not only help maintain representativeness but also allow for over-sampling, as in the 2012 wave 
over-sampling areas with high rates of international migration and allowing for a rich assessment of international, as well as internal, migration (El-Mallakh and Wahba, 2017; Mahe, 2017; Wahba, 2015b). As well as maintaining comparability with other waves and surveys, the 2018 wave had an enriched focus on economic vulnerability in the design of both the sample and questionnaire, a particularly important topic in Egypt in light of the recent economic crises and reforms as well as the subsequent COVID-19 crisis (Assaad et al., 2019; Helmy and Roushdy, 2019; Krafft et al., 2021).

This paper has detailed the key features of the new wave, including the questionnaires, fielding practices, sampling, attrition, and weighting. We have compared the results of the ELMPS 2018 on standard demographic and labor market outcomes with other contemporaneous sources in Egypt, including the LFS rounds and the 2017 and 2006 Censuses. On most measures, the ELMPS was consistent with other sources, and when differences occurred, further investigations identified key issues potentially driving differences, such as the high share of youth in recent LFS waves. Besides reproducing these standard demographic and labor market outcomes, the ELMPS goes a lot further than existing LFSs by providing both panel data and detailed retrospective data on the entire life course of individuals. These data allow for the study of dynamic phenomena such as school-to-work transitions of youth, job acquisition and separation, two-way relationships between family formation and employment, and other phenomena that require data over the entire individual trajectory rather than at a single point in time. In this wave and the 2016 wave in Jordan (Krafft and Assaad, 2021a), we drew on lessons learned from previous waves (Assaad et al., 2018) to redesign the retrospective labor market history module to improve the measurement of nonemployment spells either preceding or interspersed between employment spells. Analyses presented in this paper demonstrated that these modifications led to substantial improvements in data quality.

\subsection{Limitations}

Although the 2018 wave of the ELMPS made substantial progress in both questionnaire design and reducing attrition, there remain several limitations to the data that must be kept in mind. While attrition has been reduced and appears to be mostly random, we can only measure and account for how characteristics were observed in 2012 relating to attrition. Dynamic processes that occurred between 2012 and 2018 as well as unobservable characteristics can still bias the resulting sample, which is one of the reasons we carefully compare the results with other data sources in this paper.

Improvements in the labor market history module's design improved the detection and timing of statuses such as unemployment. However, with this and all retrospective data, recall biases remain an issue. Even in the contemporaneous data, measurement error, whether stemming from social desirability bias when answering gender role attitudes questions or challenges with survey fatigue or enumerator data entry errors remain potential problems. Continuing to update the design of the questionnaire and ensure best practices for fielding remains an important issue for the LMPS series. For example, better capturing the care economy and care work, not just market work, is an important area for future improvements, potentially including the addition of a 24-h time use diary (ERF and UN Women, 2020). 


\subsection{Directions for future research}

The longitudinal, retrospective, and rich data of the ELMPS have already begun to illustrate important developments in Egypt's economy and society, such as fertility, after rising in 20122014, once more decreasing in 2018 (Krafft et al., 2019). The rise in non-participation in the labor force (Krafft et al., 2019), and especially the high and increasing share of youth not in education nor employment (Amer and Atallah, 2019), are concerning developments that can be better understood through rigorous research using the ELMPS. These are just a few of the ways that ELMPS can contribute to our understanding of Egypt's economy and society.

\section{References}

Al-Hawarin, I.; R. Assaad; A. Elsayed (2021); Migration Shocks and Housing: Short-Run Impact of the Syrian Refugee Crisis in Jordan. Journal of Housing Economics, 53 (101761).

Amer, M.; M. Atallah (2019): The School to Work Transition and Youth Economic Vulnerability in Egypt. Economic Research Forum Working Paper Series No. 1353. Cairo, Egypt: Economic Research Forum.

Anker, R.; M. Anker (1995): Measuring Female Labour Force with Emphasis on Egypt, in: Nabil F. Khoury; Valentine M. Moghadam (eds.) Gender and Development in the Arab World: Women's Economic Participation: Patterns and Policies. United Nations University Press, 148-176.

Assaad, R. (1997): The Employment Crisis in Egypt: Current Trends and Future Prospects. Research in Middle East Economics 2(1), 39-66.

Assaad, R. (ed.) (2002), The Egyptian Labor Market in an Era of Reform. Cairo, Egypt: American University in Cairo Press.

Assaad, R. (ed.) (2009), The Egyptian Labor Market Revisited. Cairo, Egypt: American University in Cairo Press.

Assaad, R. (ed.) (2014), The Jordanian Labor Market in the New Millenium. Oxford, UK: Oxford University Press.

Assaad, R.; A. AlSharawy; C. Salemi (2019): Is The Egyptian Economy Creating Good Jobs? Job Creation and Economic Vulnerability from 1998 to 2018. Economic Research Forum Working Paper Series No. 1354. Cairo, Egypt: Economic Research Forum.

Assaad, R.; M. Arntz (2005): Constrained Geographical Mobility and Gendered Labor Market Outcomes Under Structural Adjustment: Evidence from Egypt. World Development 33(3), 431-454.

Assaad, R.; C. Binzel; M. Gadallah (2010): Transitions to Employment and Marriage Among Young Men in Egypt. Middle East Development Journal 2(1), 39-88.

Assaad, R.; S. Ghazouani; C. Krafft; D. J. Rolando (2016): Introducing the Tunisia Labor Market Panel Survey 2014. IZA Journal of Labor \& Development 5(15), 1-21.

Assaad, R.; T. Ginn; M. Saleh (2018): Impact of Syrian Refugees in Jordan on Education Outcomes for Jordanian Youth. Economic Research Forum Working Paper Series No. 1214. Cairo, Egypt: Economic Research Forum.

Assaad, R.; C. Krafft (2013): The Egypt Labor Market Panel Survey: Introducing the 2012 Round. IZA Journal of Labor \& Development 2(8), 1-30.

Assaad, R.; C. Krafft (ed.) (2015a), The Egyptian Labor Market in an Era of Revolution. Oxford, UK: Oxford University Press.

Assaad, R.; C. Krafft (2015b): Is Free Basic Education in Egypt a Reality or a Myth? International Journal of Educational Development 45, 16-30.

Assaad, R.; C. Krafft (2016a): Inequality of Opportunity in Human Development, in: Ishac D.; A. Galal (ed.), The Middle East Economies in Times of Transition. New York, NY: Palgrave Macmillan, 131-158.

Assaad, R.; C. Krafft (2016b): Labor Market Dynamics and Youth Unemployment in the Middle East and North Africa: Evidence from Egypt, Jordan and Tunisia. Economic Research Forum Working Paper Series No. 993. Cairo, Egypt: Economic Research Forum.

Assaad, R.; C. Krafft (2021): Excluded Generation: The Growing Challenges of Labor Market Insertion for Egyptian Youth. Journal of Youth Studies 24(2), 186-212.

Assaad, R.; C. Krafft; J. Roemer; D. Salehi-Isfahani (2018): Inequality of Opportunity in Wages and Consumption in Egypt. Review of Income and Wealth 64(S1), S26-S54.

Assaad, R.; C. Krafft; S. Yassin (2018): Comparing Retrospective and Panel Data Collection Methods to Assess Labor Market Dynamics. IZA Journal of Development and Migration 8(17), 1-34.

Assaad, R.; F. Roudi-Fahimi (2007): Youth in the Middle East and North Africa: Demographic Opportunity or Challenge? Population Reference Bureau Policy Brief. Washington, DC: Population Reference Bureau.

Assaad, R.; R. Roushdy (2009): Methodological Appendix 3: An Analysis of Sample Attrition in the Egypt Labor Market Panel Survey 2006. in: R. Assaad (ed.), The Egyptian Labor Market Revisited. Cairo, Egypt: American University in Cairo Press, 303-316. 
Barsoum, G. (2015): Striving for Job Security: The Lived Experience of Employment Informality among Educated Youth in Egypt. International Journal of Sociology and Social Policy 35(5), 340-358.

Beegle, K.; J. De Weerdt; S. Dercon (2011): Migration and Economic Mobility in Tanzania: Evidence from a Tracking Survey. Review of Economics and Statistics 93(3), 1010-1033.

Belhaj Hassine, N. (2011): Inequality of Opportunity in Egypt. The World Bank Economic Review 26(2), 265-295.

Bertoli, S.; F. Marchetta (2015): Bringing It All Back Home - Return Migration and Fertility Choices. World Development 65, 27-40.

Biltagy, M. (2012): Quality of Education, Earnings and Demand Function for Schooling in Egypt: An Economic Analysis. Procedia - Social and Behavioral Sciences 69, 1741-1750.

Binzel, C.; R. Assaad (2011): Egyptian Men Working Abroad: Labour Supply Responses by the Women Left Behind. Labour Economics 18(S1), S98-S114.

Brunette, W.; S. Sudar; M. Sundt; C. Larson; J. Beorse; R. Anderson (2017): Open Data Kit 2.0: A Services-Based Application Framework for Disconnected Data Management. MobiSys 2017 - Proceedings of the 15th Annual International Conference on Mobile Systems, Applications, and Services.

CAPMAS (2017): Census of Population, Housing, and Establishments 2017 (Arabic). Cairo, Egypt.

CAPMAS (2019a): Egypt Statistics Quarterly ‘Unemployment’ Rate. https://www.capmas.gov.eg/Pages/ IndicatorsPage.aspx?Ind_id=5778. Accessed 6 September 2019.

CAPMAS (2019b): Egypt Statistics Quarterly Economic Activity Rates. https://www.capmas.gov.eg/Pages/ IndicatorsPage.aspx?Ind_id=5778. Accessed 6 September 2019.

CAPMAS (2019c): Egypt in Figures 2019. Cairo, Egypt: CAPMAS.

Crandall, A.; K. Vanderende; Y. F. Cheong; S. Dodell; K. M. Yount (2016): Women's Age at First Marriage and Postmarital Agency in Egypt. Social Science Research 57, 148-160.

Dougherty, C. (2014): The Labour Market for Youth in Egypt: Evidence from the 2012 School to Work Transition Survey. Silatech Working Paper No. 14-2. Doha, Qatar: Silatech.

Economic Research Forum; UN Women (2020): Progress of Women in the Arab States 2020: The Role of the Care Economy in Promoting Gender Equality. Cairo, Egypt: UN Women.

El-Hamidi, F.; M. Said (2014): Gender-Based Wage and Occupational Inequality in the New Millenium in Egypt. The Journal of Developing Areas 48(1), 21-41.

El-Mallakh, N.; J. Wahba (2017): Return Migrants and the Wage Premium: Does the Legal Status of Migrants Matter? Economic Research Forum Working Paper Series No. 1133. Cairo, Egypt: Economic Research Forum.

El-Mallakh, N.; J. Wahba (2018): Syrian Refugees and the Migration Dynamics of Jordanians: Moving in or Moving Out? Economic Research Forum Working Paper Series No. 1191. Cairo, Egypt: Economic Research Forum.

Fallah, B.; C. Krafft; J. Wahba (2019): The Impact of Refugees on Employment and Wages in Jordan. Journal of Development Economics 139, 203-216.

Helmy, I.; R. Roushdy (2019): Household Vulnerability and Resilience to Economic Shocks. Economic Research Forum Working Paper Series No. 1362. Cairo, Egypt: Economic Research Forum.

Hendy, R; C. Zaki (2013): Assessing the Effects of Trade Liberalization on Wage Inequalities in Egypt: A Microsimulation Analysis. The International Trade Journal 27(1), 63-104.

Heyne, S.; M. Gebel (2016): Education Effects on the School-to-Work Transition in Egypt: A Cohort Comparison of Labor Market Entrants 1970-2012. Research in Social Stratification and Mobility 46, 37-49.

Himelein, K. (2014): Weight Calculations for Panel Surveys with Subsampling and Split-off Tracking. Statistics and Public Policy 1(1), 40-45.

ILO (2013): Resolution Concerning Statistics of Work, Employment, and Labour Underutilization Adopted by the Nineteenth International Conference of Labour Statisticians (October 2013).

ILO (2019): ILOSTAT.

Krafft, C. (2016): Understanding the Dynamics of Household Enterprises in Egypt: Birth, Death, Growth, and Transformation. Economic Research Forum Working Paper Series No. 983. Cairo, Egypt: Economic Research Forum.

Krafft, C. (2020): Why Is Fertility on the Rise in Egypt? The Role of Women's Employment Opportunities. Journal of Population Economics 33(4), 1173-1218.

Krafft, C.; R. Assaad (2014): Beware of the Echo: The Impending Return of Demographic Pressures in Egypt. Economic Research Forum Policy Perspective No. 12. Cairo, Egypt: Economic Research Forum.

Krafft, C.; R. Assaad (2015): Promoting Successful Transitions to Employment for Egyptian Youth. Economic Research Forum Policy Perspective No. 15. Cairo, Egypt: Economic Research Forum.

Krafft, C.; R. Assaad (2020): Employment's Role in Enabling and Constraining Marriage in the Middle East and North Africa. Demography 57(6), 2297-2325.

Krafft, C.; R. Assaad (2021a): Introducing the Jordan Labor Market Panel Survey 2016. IZA Journal of Development and Migration 12:08. 
Krafft, C.; R. Assaad (ed.) (2021b): The Egyptian Labor Market: A Focus on Gender and Economic Vulnerability (Forthcoming). Oxford, UK: Oxford University Press.

Krafft, C.; R. Assaad; C. Keo (2019): The Evolution of Labor Supply in Egypt from 1988-2018: A Gendered Analysis. Economic Research Forum Working Paper Series No. 1358. Cairo, Egypt: Economic Research Forum.

Krafft, C.; R. Assaad; M. A. Marouani (2021): The Impact of COVID-19 on Middle Eastern and North African Labor Markets: Glimmers of Progress but Persistent Problems for Vulnerable Workers a Year into the Pandemic. Economic Research Forum Policy Brief No. 55. Cairo, Egypt: Economic Research Forum.

Krafft, C.; R. Assaad; K. W. Rahman; M. Cumanzala (2020): How Do Small Formal and Informal Firms in the Arab Republic of Egypt Compare? World Bank Policy Research Working Paper Series No. 9423. Washington, DC.

Krafft, C.; A. C. Mendosa; S. Thao (2019): Internal Migration and Education: Findings from Egypt. Paper Commissioned for the Arab States 2019 Global Education Monitoring Report, Migration, Displacement and Education: Building Bridges, Not Walls.

Langsten, R.; R. Salem (2008): Two Approaches to Measuring Women's Work in Developing Countries: A Comparison of Survey Data from Egypt. Population and Development Review 34(2), 283-305.

Mahe, C. (2017): Occupational Choice of Return Migrants: Is There a 'Jack-of-All-Trades' Effect? Maastricht University Working Paper Series No. 2017-039. Maastricht, The Netherlands.

Malaeb, B.; J. Wahba (2018): Impact of Refugees on Immigrants' Labor Market Outcomes. Economic Research Forum Working Paper Series No. 1194. Cairo, Egypt, Egypt: Economic Research Forum.

Marchetta, F. (2013): Return Migration and the Survival of Entrepreneurial Activities in Egypt. World Development 40(10), 1999-2013.

Minnesota Population Center (2018): Egypt 2006. Integrated Public Use Microdata Series, International: Version 7.1. Minneapolis, MN: IPUMS.

Miyata, S.; H. Yamada (2017): Do Female Gender Role Attitudes Affect Labour Market Participation in Egypt? The Journal of Development Studies 52(6), 876-894.

OAMDI (2019a): Labor Market Panel Surveys (LMPS). Version 4.0 of Licensed Data Files; ILMPS 2019. Integrated: Economic Research Forum (ERF).

OAMDI (2019b): Labor Market Panel Surveys (LMPS). Version 2.0 of Licensed Data Files; ELMPS 2018.

OAMDI (2019C): OAMDI, 2019. Egypt - Labor Force Survey (LFS). Various Rounds. Cairo, Egypt: Economic Research Forum.

Pastore, F.; C. Quintano; A. Rocca (2021): Stuck at a Crossroads? The Duration of the Italian School-to-Work Transition. International Journal of Manpower 42(3), 442-469.

Radchenko, N. (2014): Heterogeneity in Informal Salaried Employment: Evidence from the Egyptian Labor Market Survey. World Development 62, 169-188.

Robinson, W.; F. H. El-Zanaty (2006): The Demographic Revolution in Modern Egypt. Lanham, MD: Lexington Books.

Said, M.; R. Galal; M. Sami (2019): Inequality and Income Mobility in Egypt. Economic Research Forum Working Paper Series No. 1368. Cairo, Egypt: Economic Research Forum.

Salem, R. (2016): The Gendered Effects of Labour Market Experiences on Marriage Timing in Egypt. Demographic Research 35(11), 283-314.

Selwaness, I.; C. Krafft (2021): The Dynamics of Family Formation and Women's Work: What Facilitates and Hinders Female Employment in the Middle East and North Africa? Population Research and Policy Review 40(3), 533-587.

Selwaness, I.; C. Zaki (2017): Assessing the Impact of Trade Reforms on Informal Employment in Egypt. The Journal of North African Studies 20(3), 1-24.

Vaillant, J. (2013): Attrition and Follow-up Rules in Panel Surveys: Insights from a Tracking Experience in Madagascar. Review of Income and Wealth 59(3), 509-538.

Wahba, J. (2015a): Selection, Selection, Selection: The Impact of Return Migration. Journal of Population Economics 28(3), 535-563.

Wahba, J. (2015b): Through the Keyhole: International Migration in Egypt. in: R. Assaad; C. Krafft, The Egyptian Labor Market in an Era of Revolution. Oxford, UK: Oxford University Press, 198-217.

Wahba, J.; R. Assaad (2017): Flexible Labor Regulations and Informality in Egypt. Review of Development Economics 21(4), 962-984.

World Bank (2013a): Opening Doors: Gender Equality and Development in the Middle East and North Africa. Washington, DC: World Bank.

World Bank (2013b): Jobs for Shared Prosperity: Time for Action in the Middle East and North Africa. Washington, DC: World Bank.

Yassin, S.; F. Langot (2018): Informality, Public Employment and Employment Protection in Developing Countries. Journal of Comparative Economics 46(1), 326-348. 